\title{
Observations of gas- and aerosol-phase organic nitrates at BEACHON-RoMBAS 2011
}

\author{
J. L. Fry ${ }^{1}$, D. C. Draper ${ }^{1}$, K. J. Zarzana ${ }^{2,3}$, P. Campuzano-Jost ${ }^{2,3}$, D. A. Day ${ }^{2,3}$, J. L. Jimenez ${ }^{2,3}$, S. S. Brown ${ }^{4}$, \\ R. C. Cohen ${ }^{5}$, L. Kaser ${ }^{6}$, A. Hansel ${ }^{6}$, L. Cappellin ${ }^{7}$, T. Karl $^{8}$, A. Hodzic Roux ${ }^{8}$, A. Turnipseed ${ }^{8}$, C. Cantrell $^{8}$, \\ B. L. Lefer ${ }^{9}$, and N. Grossberg ${ }^{9}$ \\ ${ }^{1}$ Department of Chemistry, Reed College, Portland, OR, USA \\ ${ }^{2}$ Department of Chemistry and Biochemistry, University of Colorado Boulder, Boulder, CO, USA \\ ${ }^{3}$ Cooperative Institute for Research in Environmental Sciences (CIRES), Boulder, CO, USA \\ ${ }^{4}$ Earth System Research Laboratory, National Oceanic and Atmospheric Administration, Boulder, CO, USA \\ ${ }^{5}$ Department of Chemistry, University of California at Berkeley, Berkeley, CA, USA \\ ${ }^{6}$ Institute for Ion Physics and Applied Physics, University of Innsbruck, Innsbruck, Austria \\ ${ }^{7}$ IASMA Research and Innovation Centre, Fondazione Edmund Mach, Food Quality and Nutrition Area, S. Michele a/A, Italy \\ ${ }^{8}$ Atmospheric Chemistry Division, National Center for Atmospheric Research, Boulder, CO, USA \\ ${ }^{9}$ Department of Earth and Atmospheric Science, University of Houston, Houston, TX, USA
}

Correspondence to: J. L. Fry (fry@ reed.edu)

Received: 23 October 2012 - Published in Atmos. Chem. Phys. Discuss.: 21 January 2013

Revised: 25 May 2013 - Accepted: 23 July 2013 - Published: 2 September 2013

\begin{abstract}
At the Rocky Mountain Biogenic Aerosol Study (BEACHON-RoMBAS) field campaign in the Colorado front range, July-August 2011, measurements of gas- and aerosol-phase organic nitrates enabled a study of the role of $\mathrm{NO}_{\mathrm{x}}\left(\mathrm{NO}_{\mathrm{x}}=\mathrm{NO}+\mathrm{NO}_{2}\right)$ in oxidation of forest-emitted volatile organic compounds (VOCs) and subsequent aerosol formation. Substantial formation of peroxy- and alkylnitrates is observed every morning, with an apparent $2.9 \%$ yield of alkyl nitrates from daytime $\mathrm{RO}_{2}+\mathrm{NO}$ reactions. Aerosol-phase organic nitrates, however, peak in concentration during the night, with concentrations up to $140 \mathrm{ppt}$ as measured by both optical spectroscopic and mass spectrometric instruments. The diurnal cycle in aerosol fraction of organic nitrates shows an equilibrium-like response to the diurnal temperature cycle, suggesting some reversible absorptive partitioning, but the full dynamic range cannot be reproduced by thermodynamic repartitioning alone. Nighttime aerosol organic nitrate is observed to be positively correlated with $\left[\mathrm{NO}_{2}\right] \times\left[\mathrm{O}_{3}\right]$ but not with $\left[\mathrm{O}_{3}\right]$. These observations support the role of nighttime $\mathrm{NO}_{3}$-initiated oxidation of monoterpenes as a significant source of nighttime aerosol. Nighttime production of organic nitrates is comparable in magnitude to daytime photochemical production at this site,
\end{abstract}

which we postulate to be representative of the Colorado front range forests.

\section{Introduction}

Nitrogen oxides affect both daytime and nighttime volatile organic compound (VOC) oxidation mechanisms, controlling tropospheric ozone formation and the branching ratios for formation of VOC oxidation products, such as organic peroxides (ROOR and $\mathrm{ROOH}$ ), alcohols and ketones $(\mathrm{ROH}$ and $\mathrm{R}=\mathrm{O})$, and multifunctional organic nitrates $\left(\mathrm{RONO}_{2}\right)$. These products can have reduced volatility making them good aerosol precursors. Figure 1 shows the general mechanisms of $\mathrm{NO}_{\mathrm{x}}$ control of VOC oxidation. First, $\mathrm{NO}_{\mathrm{x}}$ enhances nighttime or low-light oxidation by providing a source $\left(\mathrm{NO}_{2}+\mathrm{O}_{3}\right)$ of elevated $\mathrm{NO}_{3}$ (blue), adding an additional oxidation pathway. Second, during the day, directly emitted and photolytically produced NO can be elevated (red) and can control the fate of $\mathrm{RO}_{2}$ radicals, preferentially enhancing $\mathrm{RO}+\mathrm{NO}_{2}$ and $\mathrm{RONO}_{2}$ reaction channels over non-nitrate channels. With sufficiently high $\mathrm{NO}_{3}$, another nighttime $\mathrm{NO}_{\mathrm{x}}$ effect is possible: $\mathrm{NO}_{3}$ may react with 


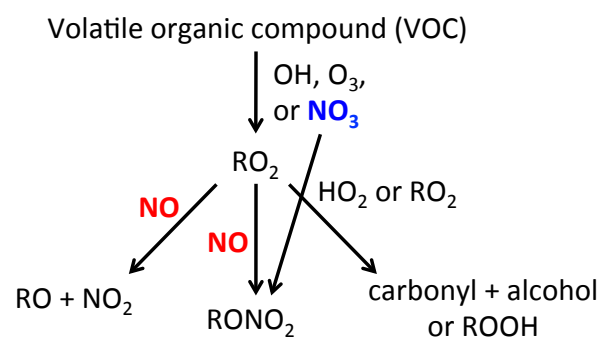

Fig. 1. Overview of potential $\mathrm{NO}_{\mathrm{x}}$ effects on the oxidation of a volatile organic compound.

$\mathrm{RO}_{2}$, effectively playing the role of daytime $\mathrm{NO}$, in competition with $\mathrm{RO}_{2}+\mathrm{RO}_{2}$ reactions. These reactions remain very poorly understood (Sommariva et al., 2012).

$\mathrm{NO}_{3}$ is the least understood of the atmospheric oxidants; its concentration is much more variable in space and time and is therefore poorly characterized. Further, since it exists at night in a stable rather than well-mixed boundary layer, surface measurements are insufficient to predict the vertical distribution of $\mathrm{NO}_{3}$.

Due to its high reactivity, the atmospheric lifetime of $\mathrm{NO}_{3}$ in forests is likely to be limited by its reaction with unsaturated hydrocarbons, especially biogenic VOCs (Winer et al., 1984; Golz et al., 2001; Fuentes et al., 2007). In urban forests, $\mathrm{NO}_{3}$ is responsible for a substantial fraction of total VOC degradation (e.g., $28 \%$ in Pabstthum near Berlin, Germany; Geyer et al., 2001).

A better understanding of the effects of $\mathrm{NO}_{\mathrm{x}}$ on secondary organic aerosol (SOA) production is a key goal of this study. A growing consensus is emerging that $\mathrm{NO}_{3}$-initiated oxidation of biogenic volatile organic compounds (BVOCs) is an important source of secondary organic aerosol (Fry et al., 2009, 2011; Pye et al., 2010; Rollins et al., 2012), suggesting that organic nitrates may be a significant fraction of aerosol composition. These nitrates may also contribute to the remaining underprediction of SOA sources: models based on laboratory-measured SOA yields from known precursor VOCs underestimate aerosol loading by from a factor of 2 (Farina et al., 2010) to up to an order of magnitude in polluted regions (de Gouw et al., 2005; Heald et al., 2005; Volkamer et al., 2006) and cannot explain the evolution of SOA (Jimenez et al., 2009). Recent explicit chemical modeling of SOA formation in Mexico City indicates SOA loading increases up to several days downwind of urban areas (Lee-Taylor et al., 2011). All of this suggests the existence of additional mechanisms of SOA formation not yet quantified in the laboratory, yields that are higher under ambient conditions than as measured in the laboratory, or the presence of significant additional VOC mass that is the precursor for aerosol formation (Donahue et al., 2006; Robinson et al., 2007). More recent modeling results can close the gap with the measurements in polluted regions, but it is unclear if this is for the right reasons (Dzepina et al., 2009; Hodzic et al.,
2010). A substantial enhancement of biogenic SOA formation due to anthropogenic pollution has been suggested as a controlling factor for SOA formation (de Gouw et al., 2005; Weber et al., 2007; Spracklen et al., 2011; Hoyle et al., 2011). Because $\mathrm{NO}_{\mathrm{x}}$ can either suppress or enhance aerosol formation, field measurements that probe $\mathrm{NO}_{\mathrm{x}} / \mathrm{SOA}$ interactions in the real atmosphere are key to evaluating the magnitude of this effect.

Here, we address the question of the fate of $\mathrm{NO}_{\mathrm{x}}$ in a pine forest, with particular focus on its influence on biogenic SOA formation. We measured selected $\mathrm{NO}_{\mathrm{y}}$ species $\left(\mathrm{NO}_{2}\right.$, peroxynitrates $(\Sigma \mathrm{PNs})$, alkyl nitrates $(\Sigma \mathrm{ANs})$, and their gas/aerosol partitioning) over a 6-week summertime campaign in a Colorado front range forest, and interpret their daily cycles with the aid of auxiliary data on $\mathrm{NO}_{3}, \mathrm{~N}_{2} \mathrm{O}_{5}$, meteorology, $\mathrm{O}_{3}$, BVOCs, radicals, and regional transport modeling. We demonstrate and quantify distinct daytime and nighttime mechanisms of organic nitrate formation, showing that even at this forested site $40 \mathrm{~km}$ from the nearest urban area (peak $\left[\mathrm{NO}_{2}\right] \approx 2 \mathrm{ppb}$ ), $\mathrm{NO}_{\mathrm{x}}$ chemistry has a substantial impact on BVOC fate and SOA formation.

\section{Experimental design}

\subsection{BEACHON-RoMBAS field site description}

The Bio-hydro-atmosphere interactions of Energy, Aerosols, Carbon, $\mathrm{H}_{2} \mathrm{O}$, Organics, and Nitrogen (BEACHON) project is a long-term, multi-institution, collaborative effort, spearheaded by the National Center for Atmospheric Research (NCAR). In July and August 2011, the Rocky Mountain Biogenic Aerosol Study (BEACHON-RoMBAS, hereinafter RoMBAS) field campaign took place, with research groups from 25 institutions participating in measurements with focus particularly on aerosol emissions and formation. The RoMBAS campaign was located in the United States Forest Service (USFS) Manitou Forest Observatory (MFO) in Pike National Forest, Colorado $\left(39.10^{\circ} \mathrm{N}, 105.10^{\circ} \mathrm{W}\right)$. The site is at $2370 \mathrm{~m}$ elevation, $40 \mathrm{~km}$ northwest of Colorado Springs and $70 \mathrm{~km}$ southwest of Denver, CO (Fig. 2). Vegetation at the site is almost entirely open-canopy ponderosa pine, but nearby areas include Douglas fir, aspen, oak, spruce, willow, and grass which may have some impact at the site. Previous studies at the site have observed dominant VOC emissions to be monoterpenes (34\% of total VOC mixing ratio) and 2-methyl-3-butene-2-ol (MBO, 50\%) during the day, with monoterpene concentrations dominant at night $(\approx 66 \%$ of VOC), comprised of a roughly equal mix of $\alpha$-pinene, $\beta$ pinene, and $\Delta$-3-carene (Kim et al., 2010). Nighttime winds at the surface were dominated by local drainage flows from the south.

During July and August 2011 the circulation and precipitation patterns over the MFO site were strongly influenced by the North American Monsoon (Hodzic et al., 2013). During 

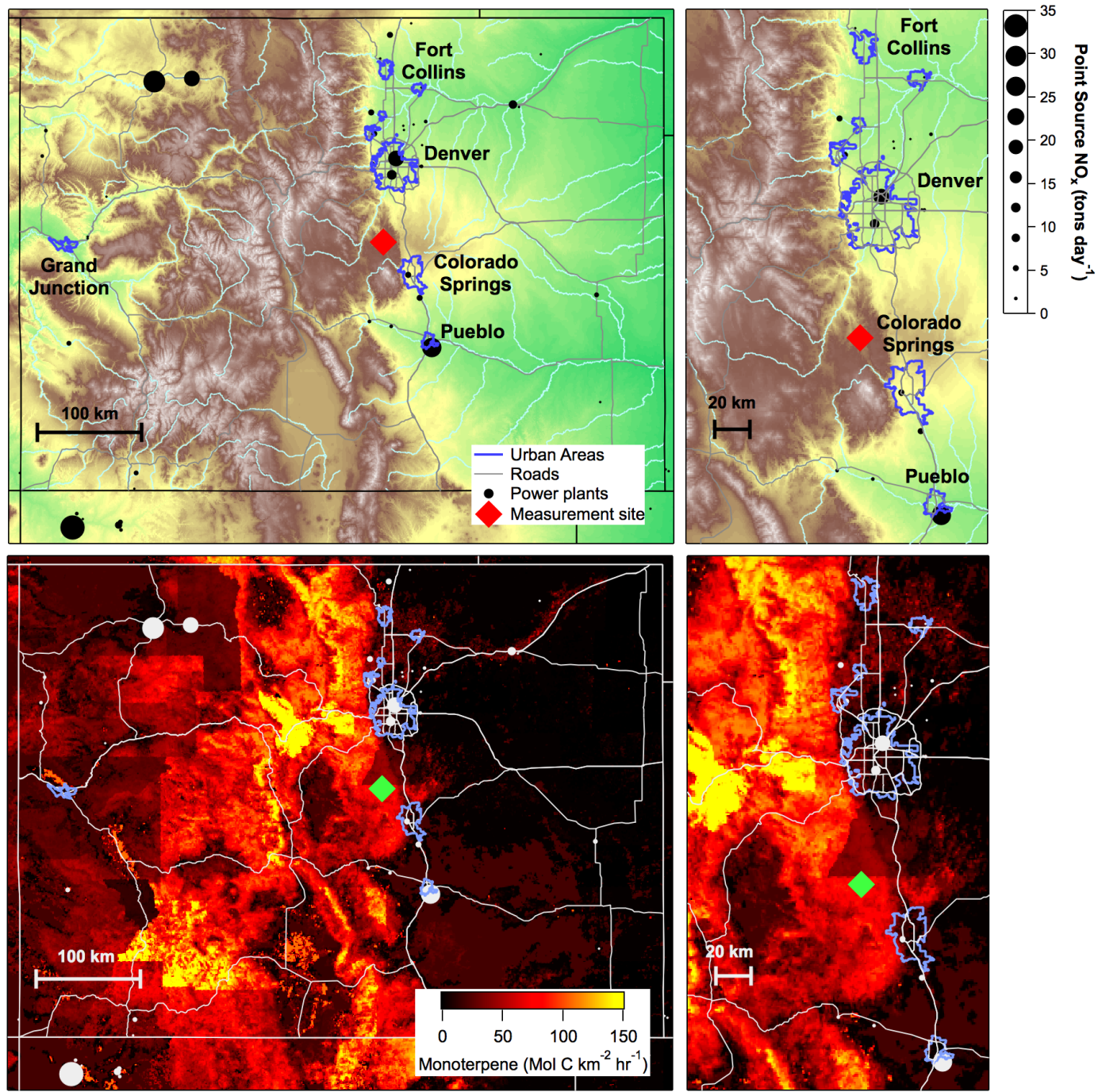

Fig. 2. Map of Manitou Forest Observatory site. Top panels show topography and point sources for $\mathrm{NO}_{\mathrm{x}}$. Regional $\mathrm{NO}_{\mathrm{x}}$ point sources are shown as black/grey dots with size proportional to emissions rate. The Four Corners power plant (lower left of larger map) is not shown on this scale; its emissions of 136 tons day $^{-1}$ dwarf all other power plants in this region. The site is $40 \mathrm{~km}$ northwest of Colorado Springs and $70 \mathrm{~km}$ southwest of Denver, the two largest urban areas (outlined in blue) in the domain. For discussion of transport to the site, note the South Platte River Valley (rivers shown in aqua) southwest from the Denver urban area towards the field site (red/green diamond). Bottom panels show monoterpene emission potential, calculated using the BEIS model.

25-28 July and 2-5 August, the presence of a strong anticyclone over the four-corners region in the southwestern US was associated with the strong southerly mid-level flow, and brought significant amount of moisture from the southeast and southwest into this region. The largest rain event occurred on the evening of 4 August and was characterized by heavy hail and rain whose 5 min intensity values exceed $120 \mathrm{~mm} \mathrm{~h}^{-1}$. During the rest of the campaign, the site was experiencing more zonal synoptic flow with mid-level winds mainly from the west and very little large-scale advection of moisture into the region.

The near-surface circulation was strongly influenced by the daytime thermally induced mountain flow that was estab- lished a few hours after sunrise on days when the synoptic forcing was weak. The upslope transport of the front range (plains) air and pollution was observed on all nights in $\mathrm{NO}_{2}$ and some days in $\mathrm{CO}$ and $\mathrm{SO}_{2}$ trace gas measurements (see discussion in Sect. 3.1.2 and Fig. 4).

The site was specifically chosen to have large biogenic emissions and limited anthropogenic influence, and one of the objectives of RoMBAS was studying the ambient submicron aerosol, presumed to be dominantly biogenic. Most chemical instruments were arranged in and on top of trailers with inlets oriented into the dominant wind, towards the south, or on a $30 \mathrm{~m}$ tower at the center of the site ("Chemistry tower"). 


\subsection{Instrumentation}

Nitrogen dioxide, the sum of total peroxy nitrates ( $\Sigma$ PNs), and the sum of total alkyl nitrates ( $\Sigma$ ANs), as well as aerosolphase-only organic nitrates, were measured by a 3-channel thermal dissociation laser-induced fluorescence (TD-LIF) instrument similar to that described in Day et al. (2002), with selective measurement of aerosol phase enabled by a modification described in Rollins et al. (2010). Briefly, the instrument thermally dissociates the different classes of $\mathrm{NO}_{\mathrm{y}}$ into $\mathrm{NO}_{2}$ at ambient pressure in three inlet channels, samples this flow through a critical orifice (dropping the pressure to $\approx 2$ Torr) into a 38-pass White cell, and measures the $\mathrm{NO}_{2}$ mixing ratio by LIF at $408 \mathrm{~nm}$. One of these channels can be optionally operated as an "aerosol-only" channel by passing sampled air first through a $10 \mathrm{~cm}$-long, $2.2 \mathrm{~cm}$ outer diameter cylindrical charcoal denuder (Mast Carbon Ltd, UK, NovaCarb F honeycomb monolith, $44 \%$ of cross-sectional area open). This denuder removes gases more efficiently than the original design; using calculations described and verified in Rollins et al. (2010), we find that at $10 \mathrm{~L}$ per minute total flow, $<0.001 \%$ of $\mathrm{NO}_{2}$ gets through this honeycomb charcoal denuder. Contributions of each class of $\mathrm{NO}_{\mathrm{y}}$ are determined by calculating the difference in $\mathrm{NO}_{2}$ concentration detected between the channels. Because peroxynitrates dissociate between 100 and $150^{\circ} \mathrm{C}$ and alkyl nitrates between 250 and $300^{\circ} \mathrm{C}$, these classes of $\mathrm{NO}_{\mathrm{y}}$ can be separately measured; e.g., the difference in $\mathrm{NO}_{2}$ signal between ambient air sampled through a $180^{\circ} \mathrm{C}$ oven $\left(\Sigma \mathrm{PNs}+\mathrm{NO}_{2}\right)$ and ambient temperature $\left(\mathrm{NO}_{2}\right)$ is attributed to $\Sigma \mathrm{PNs}$ alone. The instrument is calibrated every $3 \mathrm{~h}$ using an $\mathrm{NO}_{2}$ gas standard (4.74 ppm $\pm 2 \% \mathrm{NO}_{2}$ in $\mathrm{N}_{2}$, NIST characterized, March 2011, Scott-Marrin) diluted with zero air to 5 known concentrations in the $1-25 \mathrm{ppb}$ range, resulting in a measurement uncertainty of $5 \%$ for $\mathrm{NO}_{2}$. The accuracy of this measurement and effectiveness of the separation has been demonstrated by comparison to summed individually measured speciated peroxynitrates (Wooldridge et al., 2010) and alkyl nitrates (Perring et al., 2009; Beaver et al., 2012).

The TD-LIF instrument was run in two modes during the campaign: (1) "3-gas mode", in which the inlet ovens were held at ambient temperature, $180^{\circ} \mathrm{C}$, and $320^{\circ} \mathrm{C}$, with the denuder bypassed, to obtain $1 \mathrm{~min}$ averaged time series of separated $\mathrm{NO}_{2}, \Sigma \mathrm{PNs}$, and $\Sigma \mathrm{ANs}$; and (2) "gas/aerosol mode", in which both heated channels are held at $320^{\circ} \mathrm{C}$, with air sampled into one of the heated channels passed through the denuder, to obtain 1 min averaged time series of total $\Sigma$ PNs + $\Sigma$ ANs and aerosol-phase-only $\Sigma$ PNs $+\Sigma$ ANs (ambient temperature $\mathrm{NO}_{2}$ channel subtracted from each). It is assumed that the aerosol-phase organic nitrates will consist predominantly of alkyl nitrates, due to the short lifetime of PANs. To the best of our knowledge, PANs have not been measured in the aerosol condensed phase, and a recent intercomparison study of aerosol alkyl nitrates (FTIR) with $\Sigma$ PNs $+\Sigma$ ANs
(TD-LIF) finds that aerosol-phase $\Sigma$ PNs $+\Sigma$ ANs are dominated by alkyl nitrates (Rollins et al., 2012).

$\mathrm{NO}_{3}$ and $\mathrm{N}_{2} \mathrm{O}_{5}$ were measured in situ by cavity ringdown spectroscopy (CRDS) using the $662 \mathrm{~nm}$ absorption band of $\mathrm{NO}_{3}$, detecting $\mathrm{N}_{2} \mathrm{O}_{5}$ via its thermal conversion to $\mathrm{NO}_{3}$ (Brown et al., 2001, 2003b, 2007; Wagner et al., 2011). The instrument used a diode laser, tunable over a narrow range near the $662 \mathrm{~nm}$ absorption of $\mathrm{NO}_{3}$, to pump two separate optical cavities, each constructed of two high-reflectivity mirrors ( $R=99.999 \%$ or better). The laser is modulated as a square wave at $500 \mathrm{~Hz}$, and the single exponential ringdown transients following the falling edge of the square wave are co-added and fit at $4 \mathrm{~Hz}$ to measure total optical extinction, $\alpha$, according to Eq. (1):

$\alpha=\left[\mathrm{NO}_{3}\right] \sigma_{\mathrm{NO}_{3}}=\frac{R_{\mathrm{L}}}{c}\left(\frac{1}{\tau}-\frac{1}{\tau_{0}}\right)$.

Here $\tau$ and $\tau_{0}$ are exponential intensity decay time constants in the presence and absence of the absorber, respectively; $c$ is the speed of light; $R_{\mathrm{L}}$ is a geometric design factor to account for the fraction of the cavity length occupied by purge volumes that keep the mirrors clean (typically $\left.R_{\mathrm{L}}=1.15\right)$; and $\left[\mathrm{NO}_{3}\right]$ and $\sigma\left(\mathrm{NO}_{3}\right)$ are the $\mathrm{NO}_{3}$ number density (molecules $\mathrm{cm}^{-3}$ ) and absorption cross section $\left(\mathrm{cm}^{2}\right.$ molecule $\left.^{-1}\right)$, respectively. Values of $\tau_{0}$ vary from 250 to $450 \mu \mathrm{s}$, equivalent to $75-135 \mathrm{~km}$ in effective path length, to provide a limit of detection of 1 pptv $(2 \sigma)$ for $\mathrm{NO}_{3}$ and $\mathrm{N}_{2} \mathrm{O}_{5}$. The $\tau_{0}$ is measured by addition of $\mathrm{NO}$ to chemically destroy $\mathrm{NO}_{3}$ via the rapid reaction $\mathrm{NO}+\mathrm{NO}_{3} \rightarrow 2 \mathrm{NO}_{2}$. The combination of $662 \mathrm{~nm}$ extinction and NO titration is a specific technique for ambient air $\mathrm{NO}_{3}$ measurement. The concentration of the sum of $\mathrm{NO}_{3}$ and $\mathrm{N}_{2} \mathrm{O}_{5}$ is measured simultaneously by thermal decomposition of $\mathrm{N}_{2} \mathrm{O}_{5}$ to $\mathrm{NO}_{3}$ in a second optical cavity that samples through a heated section of tubing $\left(120^{\circ} \mathrm{C}\right)$ and that is maintained at $75^{\circ} \mathrm{C}$. To achieve high sensitivity, both channels sample through a Teflon membrane filter that removes aerosol; filters are changed hourly using an automated device to maintain their cleanliness and transmission of $\mathrm{NO}_{3}$ and $\mathrm{N}_{2} \mathrm{O}_{5}$. The instrument has an overall accuracy of $-9 /+12 \%$ for $\mathrm{NO}_{3}$ and $-8 /+11 \%$ for $\mathrm{N}_{2} \mathrm{O}_{5}$, calibrated by separately measuring the $\mathrm{NO}_{2}$ produced from the same chemical titration reaction used to zero the instrument (Fuchs et al., 2008).

Ambient $\mathrm{NO}_{2}$ was also measured continuously by a chemiluminescent $\mathrm{NO}_{\mathrm{x}}$ box (Thermo 17i), which agreed within $8 \%$ with the TD-LIF ambient temperature $\left(\mathrm{NO}_{2}\right)$ channel for all periods when both instruments were sampling ambient air, $\approx 14$ days over the course of the campaign (the TD-LIF was used for other measurements for substantial periods). Because the $\mathrm{NO}_{\mathrm{x}}$ box monitored ambient air continuously, producing a 32-day record, while agreeing well with the more selective TD-LIF measurement of $\mathrm{NO}_{2}$ during periods of overlap, the longer $\mathrm{NO}_{\mathrm{x}}$ box time series will be used in e.g. computing diurnal averages. Inlets for this instrument as well as $\mathrm{CO}$ and $\mathrm{SO}_{2}$ monitors were 
located at $\approx 3 \mathrm{~m}$. Ozone was measured by UV absorption spectroscopy (2B Technologies, Model 205) and sulfur dioxide by pulsed fluorescence (Thermo Environmental Model 43C-TLE) at 6 different heights along the Chemistry tower $(z=1.6,5.0,8.5,12.0,17.7$ and $25.1 \mathrm{~m})$. These inlets were sampled sequentially every $5 \mathrm{~min}$, yielding a complete profile every $30 \mathrm{~min}$; for this work, only concentration data at the lowest height of $1.6 \mathrm{~m}$ were used. Carbon monoxide was measured at $3.5 \mathrm{~m}$ by a Thermo Environmental Gas Filter Correlation $\mathrm{CO}$ analyzer (Model 48 equipped with a heated $\mathrm{Pt}$ catalytic converter). Wind speed/direction, temperature and relative humidity were measured at 4 heights $(z=1.8$, 7.0, 14.1 and $27.8 \mathrm{~m}$; Vaisala, Model WXT520). Net radiation (visible + IR, incoming - outgoing) was measured at $27.8 \mathrm{~m}$ (Radiation and Energy Balance Systems, Inc., Model $\mathrm{Q} * 7.0$ net radiometer). Turbulence measurements were made at $z=25.1 \mathrm{~m}, \approx 9 \mathrm{~m}$ above the canopy height, by a 3dimensional sonic anemometer (Campbell Scientific, CSAT$3)$. From these flux measurements, the Obukhov length $(L)$ can be determined (Stull, 1998), which is a surface layer scaling parameter that gives the ratio of buoyant to mechanically (shear) generated turbulence, which can be used as a measure of atmospheric stability. When $L> \pm 130 \mathrm{~m}(|z / L|<0.1)$, shear forces dominate and the atmosphere has nearly neutral thermal stability. At values less than $\pm 100 \mathrm{~m}$, convective forces become increasingly important and denote an atmosphere that is either thermally stable $(|z / L|>0)$ or unstable $(|z / L|<0)$.

VOCs were measured using two proton-transfer-reaction time-of-flight mass spectrometers (PTR-ToF-MS, Ionicon Analytik GmbH, Austria, Jordan et al., 2009; and University of Innsbruck, Graus et al., 2010). Ambient air was sampled at a flow rate of $\approx 9$ SLPM through a $40 \mathrm{~m}$-long Teflon (PFA) line (1/4" OD) mounted at $25.3 \mathrm{~m}$ on the Chemistry tower. Both instruments were sampling off the same line with a sampling period of about $10 \mathrm{~s}$ (NCAR) and $0.1 \mathrm{~s}$ (UIBK). The merged dataset was averaged to $6 \mathrm{~min}$. The drift tube was operated at $2.3 \mathrm{mbar}$ (both instruments) and a drift voltage of $580 \mathrm{~V}$ (UIBK) and $550 \mathrm{~V}$ (NCAR) and a drift tube temperature of $60^{\circ} \mathrm{C}$ (both instruments). Calibration was performed by dynamically diluting the VOC standards to ppbv levels using purified ambient air. Details about the data evaluation can be found in Müller et al. (2010), Kaser et al. (2013), and Cappellin et al. (2011).

Submicron particle size distributions $(20-800 \mathrm{~nm})$ were measured with a Brechtel Manufacturing, Inc. scanning electrical mobility spectrometer (SEMS, Model 2002). From these size distributions, total particle surface area per volume can be calculated, and assuming a density of $1.3 \mathrm{~g} \mathrm{~cm}^{-3}$, aerosol mass loading can be determined.

An Aerodyne high-resolution time-of-flight aerosol mass spectrometer (HR-ToF-AMS; hereafter AMS; DeCarlo et al., 2006), was operated in close vicinity $(\approx 10 \mathrm{~m} \mathrm{NW})$ to the TD-LIF instrument during RoMBAS. Ambient aerosols in the AMS are analyzed by impaction/vaporization of the aerosol on a porous tungsten vaporizer at $600{ }^{\circ} \mathrm{C}$ and subsequent ionization of the gas plume by electron impact; ions are mass analyzed by a high-resolution time-of-flight mass spectrometer. The AMS quantifies non-refractory submicron aerosol, which includes organic species and most inorganic salts and organic species, but not black carbon. Refractory nitrates such as $\mathrm{Ca}\left(\mathrm{NO}_{3}\right)_{2}$ and $\mathrm{NaNO}_{3}$ can be detected by the AMS; however, they are typically associated with reacted mineral dust and marine aerosol, respectively, both of which only have small fractions in the submicron regime that were likely negligible during RoMBAS.

The AMS sampled ambient aerosol from an inlet at the same height inside the forest canopy as the TD-LIF instrument; a $\mathrm{PM}_{2.5}$ cyclone was used to prevent large dust particles from entering the instrument, and sample air was drawn from the inlet into the temperature-controlled trailer through a 3/8-inch o.d. copper tube at $10 \mathrm{lpm}$. Ambient data used in this work was acquired every $10 \mathrm{~min}$ for $2.5 \mathrm{~min}$-long intervals using the lower mass-spectral resolution, highersensitivity mode of the AMS ("V-mode"). The AMS was calibrated every four days with ammonium nitrate aerosol of known mass, and calculated submicron aerosol volumes derived from these calibrations agreed well with volumes from a collocated SMPS. The overall accuracy of the AMS for ground measurements has been estimated to be about $30 \%$ for all AMS species (Middlebrook et al., 2012; Hayes et al., 2012), with better accuracy for ratios due to error cancellation. The precision is significantly better: about $4 \mathrm{ng} \mathrm{m}^{-3}$ for aerosol nitrate and $30 \mathrm{ng} \mathrm{m}^{-3}$ for OA for the time resolution used here. The low nitrate and high organic aerosol concentrations require careful analysis of the HR spectra, taking into account the contributions of otherwise unimportant isotopic air interferences such as $\mathrm{C}^{18} \mathrm{O}^{+}$and $\mathrm{C}^{18} \mathrm{OO}^{+}$to the signals at $m / z 30$ and 46 , respectively.

\subsection{Regional modeling}

The 3-D Weather Research and Forecasting model coupled with chemistry (WRF-Chem; Grell et al., 2005) was applied to study the transport and chemistry of biogenic and anthropogenic pollutants at the MFO site from 25 July to $26 \mathrm{Au}-$ gust 2011. The chemistry was simulated using the SAPRC99 gas-phase chemical mechanism (Carter, 2000) and the MOSAIC aerosol module with 4 size bins (Zaveri et al., 2008). Organic aerosols were treated as described in Hodzic et al. (2012), and several anthropogenic CO tracers were added to monitor the transport of anthropogenic pollution to the site.

The simulations were performed using two nested domains: a coarse-scale $36 \mathrm{~km}$ horizontal resolution grid covering the western and central US and a fine-scale $4 \mathrm{~km}$ grid covering Colorado. The anthropogenic emissions come from the 2005 US EPA National Emission Inventory (NEI), while the biogenic emissions are calculated online using the MEGAN model (Guenther et al., 2006). The initial and boundary conditions for the meteorological variables are taken every 
$6 \mathrm{~h}$ from the NCEP North American Regional Reanalysis, and gas-phase and aerosol variables were obtained from the MOZART4 global chemistry-transport model. The model performance in simulating the meteorology, boundary layer height, and the concentrations of the main gas-phase pollutants during RoMBAS has been evaluated in detail in Hodzic et al. (2013).

\subsection{Predicting gas/aerosol partitioning of organic nitrates}

Direct measurements of gas/aerosol partitioning of these organic nitrates can provide insights into relative volatilities of daytime vs. nighttime $\mathrm{RONO}_{2}$, and hence the role of $\mathrm{NO}_{\mathrm{x}}$ in SOA formation. Interpreting these observations in terms of chemical mechanisms, however, requires some way to connect chemical structures to a predicted partitioning. We choose to model gas/aerosol partitioning in terms of an absorptive partitioning formalism (assuming no solid phase), following Pankow (1994) and Capouet and Müller (2006). The partitioning coefficient, $K_{\mathrm{p}}$, is defined as

$K_{\mathrm{p}}=\frac{F / \mathrm{TSP}}{A}=\frac{760 \cdot R \cdot T \cdot f_{\mathrm{om}}}{\mathrm{MW}_{\mathrm{om}} \cdot 10^{6} \cdot \zeta \cdot p_{\mathrm{vap}}}$.

$F$ and $A$ are the total aerosol-phase and gaseous concentrations of the compound of interest, and TSP is the concentration of total suspended particulate matter. In the second expression showing the equilibrium constant in terms of thermodynamic properties, $R$ is the universal gas constant $\left(8.314 \mathrm{~J} \mathrm{~mol}^{-1} \mathrm{~K}^{-1}=8.206 \times 10^{-5} \mathrm{~atm} \mathrm{~m}^{3} \mathrm{~K}^{-1} \mathrm{~mol}^{-1}\right)$, $T$ is temperature $(\mathrm{K}), f_{\mathrm{om}}$ is the weight fraction of organic matter in the total aerosol (assumed $=1$ ), $\mathrm{MW}_{\text {om }}$ is the average molecular weight of the absorbing organic material $\left(\mathrm{g} \mathrm{mol}^{-1}\right), \zeta$ is the activity coefficient of the compound of interest in the condensed phase (assumed $=1$ ), and $p_{\text {vap }}$ is the subcooled vapor pressure of the compound of interest (Torr); $760\left(\right.$ Torr atm $\left.^{-1}\right)$ and $10^{6}\left(\mu \mathrm{gg}^{-1}\right)$ are conversion factors to give $K_{\mathrm{p}}$ in units of $\mathrm{m}^{3} \mu \mathrm{g}^{-1}$.

Vapor pressures calculated in this paper are also reported as saturation mass concentrations $\left(C^{*}\right)$ for ease of comparison with volatility basis set parameterizations (Donahue et al., 2006). These saturation densities can be calculated as

$C^{*}=\frac{1}{K_{\mathrm{p}}}$

using the same variables shown above to determine $K_{\mathrm{p}}$, yielding $C^{*}$ in units of $\mu \mathrm{g} \mathrm{m}^{-3}$.

As pointed out by Barley and McFiggans (2010), a significant uncertainty in this method can arise from the variation in vapor pressure values predicted by different group contribution estimation methods. We use the SIMPOL.1 method here (Pankow and Asher, 2008), with primary focus on the temperature and TSP dependence over a daily cycle for a given molecular structure, rendering the exact predicted $p_{\text {vap }}$ values less important than relative changes.

\section{Results and discussion}

\subsection{Reasons for elevated $\mathrm{NO}_{\mathrm{x}}$ and organic nitrate concentrations at RoMBAS}

\subsubsection{Observed diurnal cycles in oxidants, BVOCs, meteorology, and photochemical age markers}

Figure 3 shows averaged daily cycles in the concentrations of oxidant and terpenoid gases that form the background and reactants for the observed $\mathrm{NO}_{\mathrm{y}}$ chemistry, as well as relevant meteorological variables and an indicator of airmass age with respect to anthropogenic pollution. Ozone (measured at $h=1.6 \mathrm{~m}$ ) shows a typical photochemistry- and depositiondriven daily cycle, peaking at an average concentration of $60 \mathrm{ppb}$ in the late afternoon and decreasing to $30 \mathrm{ppb}$ during the night. $\mathrm{NO}_{2}$ shows the opposite diurnal pattern, peaking at an average concentration of $2 \mathrm{ppb}$ at night and sinking below $0.5 \mathrm{ppb}$ during the day. The diurnal $\mathrm{NO}_{2}$ pattern is explored below in Sect. 3.1.2.

BVOC concentrations measured by PTR-ToF-MS are dominated at night by the sum of all monoterpenes (measured as $m / z$ 137.134 $\left(\mathrm{C}_{10} \mathrm{H}_{17}^{+}\right)$and $m / z$ 81.071 $\left(\mathrm{C}_{6} \mathrm{H}_{9}^{+}\right)$, peak diurnal average concentration of about $0.6 \mathrm{ppb}$ ) and during the day by the sum of MBO and isoprene (measured as $\mathrm{m} / \mathrm{z}$ $87.081\left(\mathrm{C}_{5} \mathrm{H}_{11} \mathrm{O}^{+}\right)$and $\mathrm{m} / z 69.070\left(\mathrm{C}_{5} \mathrm{H}_{9}^{+}\right)$, peak average concentration of about 1.8 in the early morning, $\approx 1.5 \mathrm{ppb}$ throughout the day). This suggests a very large daytime photo-induced emission of MBO, since this morning peak occurs simultaneously with an increase in convective vertical mixing which effectively dilutes all species. Furthermore, this morning peak (9:00-10:30 LT) coincides with an observed downward flux of $\mathrm{CO}_{2}$ above the canopy (not shown), suggesting a maximum in photosynthetic activity. This transition is shown by the Obukhov stability parameter $(z / L$ in Fig. 3) changing from a positive to negative sign. At this point, the temperature structure switches from a stable nighttime inversion to a daytime positive lapse rate with higher temperatures at the surface. Local wind direction is consistently from the south, with greater variability during the day and early evening.

We also use PTR-ToF-MS measurements of two aromatic hydrocarbons, xylene and benzene, to establish the diurnal changes in average photochemical age of the pollution contained in the airmass. Because xylene and benzene are typically co-emitted by fossil fuel and combustion sources which are common in urban areas, their ratio can provide information about photochemical airmass age. $\mathrm{Xy}$ lene is measured at $m / z \quad 107.086\left(\mathrm{C}_{8} \mathrm{H}_{11}^{+}\right)$, as a mixture of ortho-, para-, and meta-isomers, ethylbenzene, and negligible contributions from the pinonaldehyde fragment. Benzene is measured at $m / z 79.055\left(\mathrm{C}_{6} \mathrm{H}_{7}^{+}\right)$. Both were measured with concentrations in the $10-100 \mathrm{ppt}$ range over the course of the campaign. The time rate of change in the ratio of xylene : benzene provides information on the photochemical 

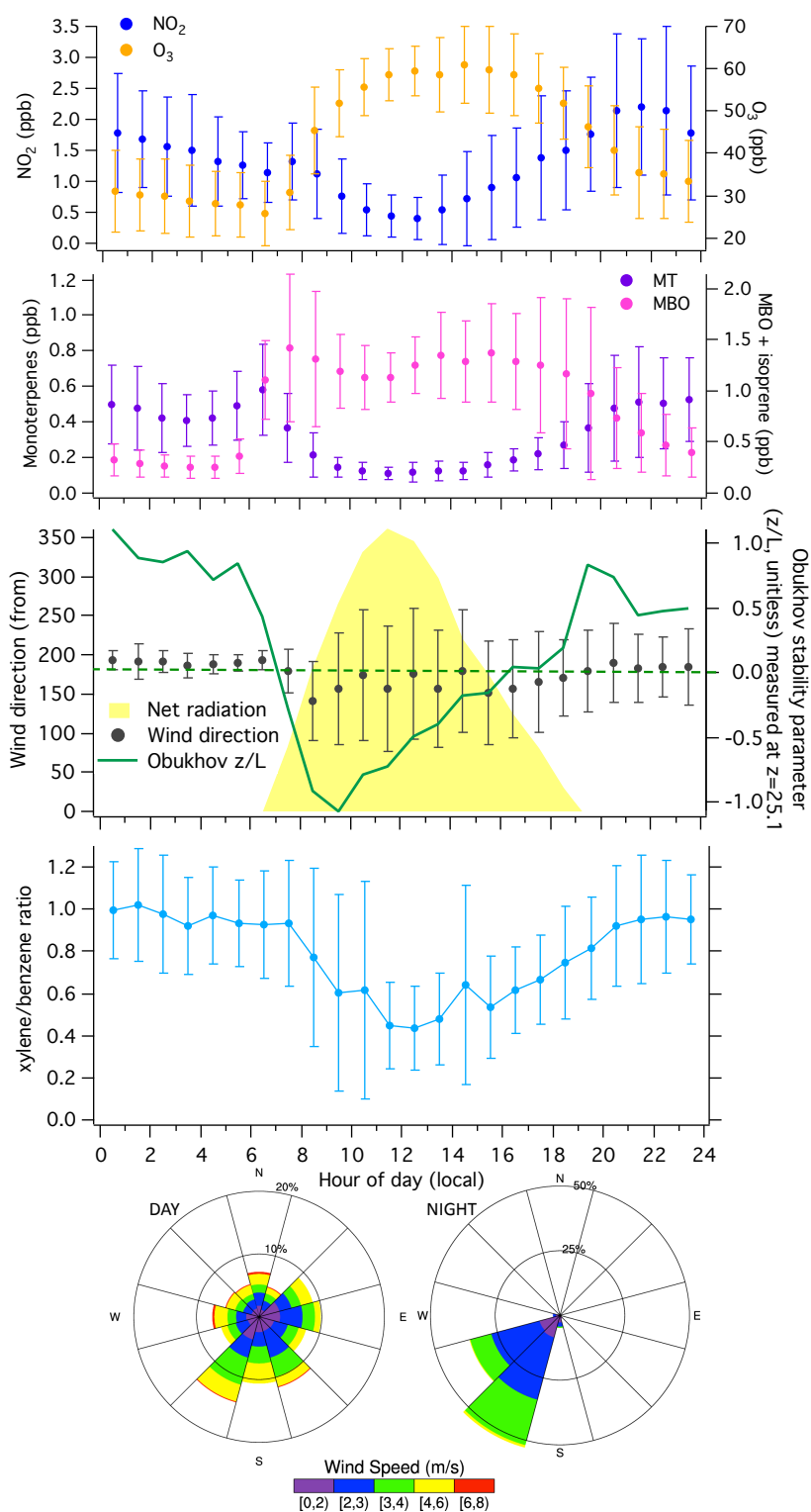

Fig. 3. Hourly binned average diurnal trends in $\mathrm{NO}_{2}$ (blue), $\mathrm{O}_{3}$ (orange), monoterpenes (purple), methyl butenol and isoprene (pink), wind direction (grey), radiation (yellow, arbitrary units), Obukhov length (green), xylene-to-benzene ratio (aqua), and average day and night windroses at MFO, 21 July-24 August 2011. Error bars are $1 \sigma$ based on data averaged to a one-hour timebase; all points are averaged for the same hour intervals but offset slightly on some plots to make error bars easier to read. Concentrations of $\mathrm{NO}_{2}$ and monoterpenes peak at night when they are concentrated in a shallow boundary layer, while $\mathrm{O}_{3}$ and $\mathrm{MBO}$ peak during the day. Winds are dominantly from the south, with more variability during the day; every morning at sunrise the Obukhov length shows a transition from a stable nighttime inversion to a convectively mixed boundary layer, and decreasing xylene : benzene ratio shows aging. age of the airmass; since the $\mathrm{OH}$ rate constants of these species are different, the xylene : benzene decreases with aging. We note that this ratio provides no information on the age of the biogenic gases or aerosol in the airmass. This analysis is described below in Sect. 3.1.3.

\subsubsection{Information from tracers: modeled and measured}

Results from the WRF-Chem simulation from the early part of the campaign are shown in Fig. 4. The anthropogenic front range $\mathrm{CO}$ tracers suggest the frequent occurrence of transport of polluted air from both Denver and Colorado Springs to MFO. This transport occurs in the early afternoon within a well-developed boundary layer. Peaks in observed $\left[\mathrm{SO}_{2}\right]$ occur most often during the day, and often coincide with peaks in anthropogenic tracers from either Denver or Colorado Springs, indicating the arrival of pollution plumes at the site. The sharper spikes in predicted surface $\mathrm{NO}_{2}$ concentrations are also coincident with the presence of anthropogenic tracers at MFO; e.g., the $\mathrm{NO}_{2}$ spike that was measured and predicted on 27 July is coincident with the modeled arrival of a concentrated Denver plume.

The regular, broader nighttime peaks in $\mathrm{NO}_{2}$ are also predicted by the model (see e.g. 6-8 August), though the accuracy of the concentration prediction varies. Rather than individual concentrated plumes as for $\mathrm{SO}_{2}$, this $\mathrm{NO}_{2}$ appears to arise from a more regional background, consistent with the importance of a few point sources (coal-fired power plants) for $\mathrm{SO}_{2}$ vs. the much larger contribution of area sources (vehicles) for $\mathrm{NO}_{\mathrm{x}}$. Also note that $\mathrm{SO}_{2}$ peaks are often not coincident with $\mathrm{NO}_{2}$ or Denver/Colorado Springs anthropogenic tracer peaks, suggesting distinct sources. Examination of regional topography (Fig. 2) reveals that the Denver plume could be transported up the Platte River canyon during daytime upslope flow that is characteristic of the Rocky Mountain foothills, and dispersed into the valley where the MFO site is located in late afternoon and evening, potentially leading to these higher nighttime concentrations of urban pollutants. Diurnal variation in measured CO concentration (not shown) almost always tracks $\mathrm{NO}_{2}$, showing the same broad nighttime peaks, consistent with this idea of a dispersed urban source of $\mathrm{NO}_{2}$ to MFO.

An alternative explanation for the broad nighttime peaks in $\mathrm{NO}_{2}$ concentration could be natural emissions of nitrogen oxides from local soils, emitted as NO but immediately titrated to $\mathrm{NO}_{2}$ by $\mathrm{O}_{3}$. This appears to be contradicted, however, by the correlation of $\mathrm{NO}_{2}$ with $\mathrm{CO}$, as well as the observed sharp early evening increases in $\mathrm{NO}_{2}$ concentration, followed by either flat or decreasing concentrations overnight. If the cause were NO emissions into a shallow nocturnal boundary layer, the concentration increase should continue throughout the night, as observed by, e.g., Aneja et al. (1996). In that study in the southeastern US, the authors used a dynamic flux chamber to quantify the nitrogen flux from soils, which they found to be $\approx 0.1 \mathrm{ppb} \mathrm{NO}_{2} \mathrm{~h}^{-1}$. 


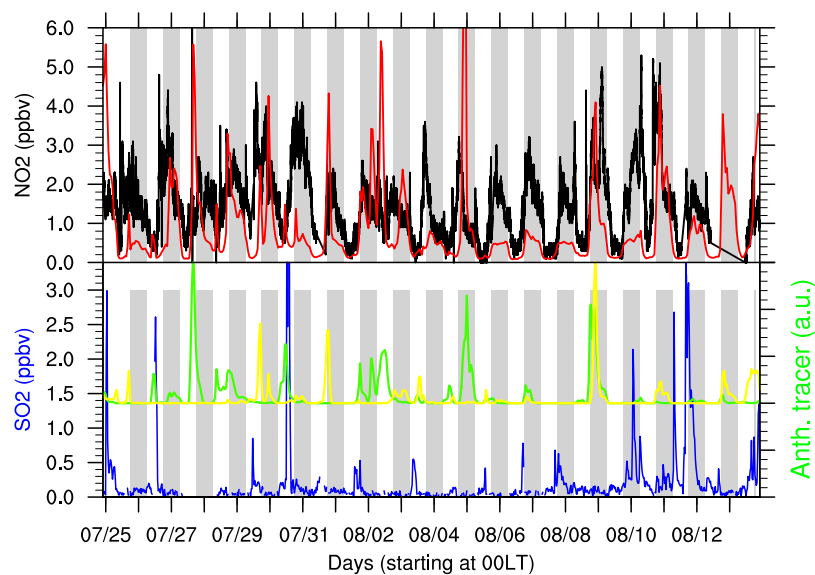

Fig. 4. Time series of $\mathrm{NO}_{2}$ (black, Thermo 17i) and $\mathrm{SO}_{2}$ (blue) surface concentrations as observed at the MFO site during the early stages of RoMBAS from 26 July to 14 August 2011. The WRFChem-predicted $\mathrm{NO}_{2}$ is also shown (red, ppbv), as well as the levels of advected anthropogenic tracers (arbitrary units) from Denver (green) and Colorado Springs (yellow). Grey shadings indicate nighttime periods (8 p.m.-8 a.m.).

Rates of increase observed at RoMBAS were typically of order $1 \mathrm{ppb} \mathrm{NO} \mathrm{N}^{-1}$, with large variability in timing and rate of increase. The terrain and transport at RoMBAS is complex, with downslope drainage flows advecting past the site at night. This makes it far more likely that observed sharp increases in $\mathrm{NO}_{2}$ arrive with this advected plume, rather than resulting from local soil $\mathrm{NO}_{\mathrm{x}}$ production: a buildup of soil $\mathrm{NO}_{\mathrm{x}}$ would be diluted out by this drainage flow and cause decreasing $\mathrm{NO}_{\mathrm{x}}$.

\subsubsection{Observed ambient PNs and ANs}

While $\mathrm{NO}_{2}$ peaks during the night, the diurnal pattern in peroxynitrates ( $\Sigma$ PNs) and alkyl nitrates ( $\Sigma$ ANs) is different (top panel of Fig. 5). Both $\Sigma$ PNs and $\Sigma$ ANs peak during the day, with increases of $\approx 200$ ppt in both cases, relative to nighttime concentrations. This increase in concentration occurs coincident with the increased vertical mixing accompanying the switch from nighttime temperature inversion to daytime positive lapse rate, as described in Sect. 3.1.1. A recent comparison (Wooldridge et al., 2010) of ambient $\Sigma$ PN measurements shows typical mean concentrations below $500 \mathrm{ppt}$ (except in urban areas where $\Sigma$ PNs are up to a few ppb), with peak concentration during the day. At another pine forested site downwind of an urban area (BEARPEX, $75 \mathrm{~km}$ northeast of Sacramento), mean $\Sigma$ PN concentration was $\approx 400 \mathrm{ppt}$, while $\Sigma$ ANs were found to increase from $\approx 300$ to $\approx 600$ ppt in the morning (Beaver et al., 2012).

There is no substantial change in local wind direction coincident with the increase in $[\Sigma \mathrm{PNs}]$ and $[\Sigma \mathrm{ANs}]$, though the local winds are overall weaker and more mixed in direc-

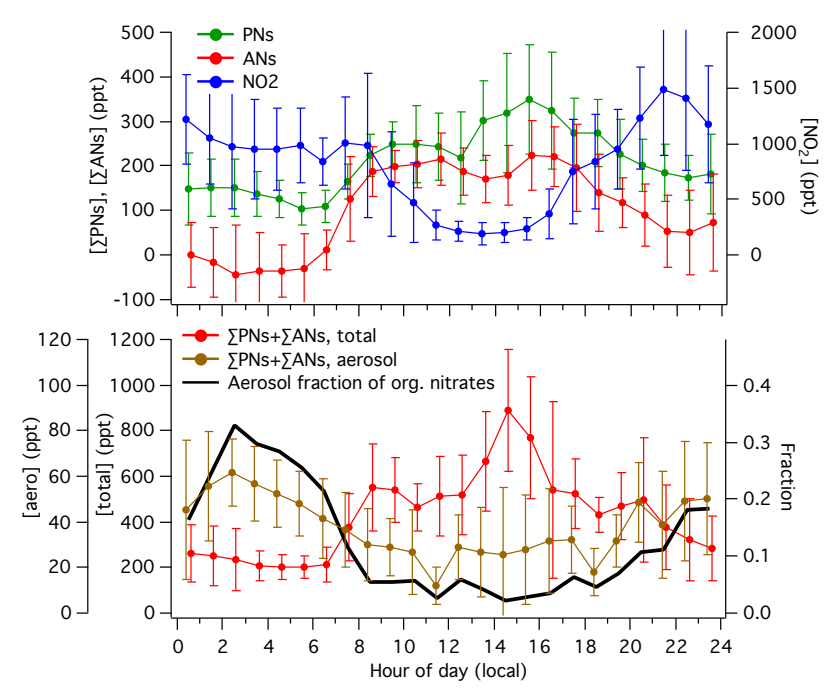

Fig. 5. Hourly binned average diurnal trends in (top): $\mathrm{NO}_{2}$ (blue), $\Sigma$ PNs (green), and $\Sigma$ ANs (red) from times when the TD-LIF was running in "3-gas" mode (13-17 and 19-20 August); and (bottom): total $\Sigma$ PNs $+\Sigma$ ANs (red), aerosol-phase-only $\Sigma$ PNs $+\Sigma$ ANs (brown), and fraction of organic nitrates in the aerosol phase (black) from times when the TD-LIF was running in "gas/aerosol" mode (28 July-1 August, 20-22 August). Error bars are $1 \sigma$ based on data averaged to a one-hour timebase; all points are averaged for the same hour intervals but offset slightly on some plots to make error bars easier to read. The $\mathrm{NO}_{2}$ trace looks slightly different than Fig. 3 because this data comes only from the subset of campaign days when the TD-LIF was running in "3-gas" ambient mode.

tion during the day than at night. This rules out the possibility that sampling air from a different source region is responsible for the increase. Because the increase in concentration is coincident with increasing vertical mixing, a second possible explanation is that higher- $\mathrm{NO}_{\mathrm{y}}$ air from above mixes down in the morning. The observations would require that the residual layer above the nocturnal boundary layer consist of essentially $\mathrm{NO}_{2}$-free air with higher concentrations of $\Sigma$ PNs and $\Sigma$ ANs, more "aged" forms of $\mathrm{NO}_{\mathrm{y}}$.

The available data do not support a solely vertical mixing explanation for the increase in $[\Sigma \mathrm{PNs}]$ and $[\Sigma \mathrm{ANs}]$; the ratio of xylene to benzene is observed to decrease relatively slowly at daybreak in the mean (Fig. 3). Roberts et al. (1984) showed that fresh emissions have a characteristic ratio of aromatic hydrocarbons, which change with age. In the case of the xylene-to-benzene ratio, fresh urban emissions have xylene: benzene of 1.3 (Harley et al., 1992) to 2 (Fraser et al., 1998; Schauer et al., 2002). Peak observed xylene : benzene at MFO occurs at night, with an average ratio of $\approx 1$. This ratio decreases at daybreak, consistent with photochemical aging, as the rate constant of xylene with OH $\left(1.5 \times 10^{-11}\right.$ molecules $\mathrm{cm}^{-3} \mathrm{~s}^{-1}$; Roberts et al., 1984) is an order of magnitude faster than benzene with $\mathrm{OH}(1.2 \times$ $10^{-12}$ molecules $\mathrm{cm}^{-3} \mathrm{~s}^{-1}$; Atkinson et al., 2004). At the 
observed morning MFO [OH] of $2.5 \times 10^{6}$ molecules $\mathrm{cm}^{-3}$ (Kim et al., 2013), these rate constants lead to the prediction that photochemical aging from xylene : benzene of 1 to 0.5 would take $\approx 5-6 \mathrm{~h}$. In fact, we observe this decrease in the ratio over $5 \mathrm{~h}$ in the diurnally averaged (mean) data (Fig. 3). Because this increase in average photochemical age corresponds to the actual clock age and tracks with the increase in $[\Sigma \mathrm{PNs}]$ and [ $\Sigma \mathrm{ANs}]$, actual aging is more likely to explain this timing than the downward mixing of more aged air aloft in the morning. We note, however, that there are some days on which the xylene : benzene ratio decreases more rapidly, which would be consistent with aged aloft air contributing on occasion.

The final possible explanation for the morning increase in $[\Sigma \mathrm{PNs}]$ and $[\Sigma \mathrm{ANs}]$ is that a significant photochemical source exists that initiates at daybreak, converting local VOCs that have built up overnight to these more highly oxidized $\mathrm{NO}_{\mathrm{y}}$. This is corroborated by an observed increase in [OH] from 1 to $3 \times 10^{6}$ between 7:00-9:00 LT (Kim et al., 2013). This photochemical processing is intertwined with tropospheric ozone production, and that chemistry can be used to determine a branching ratio of alkyl nitrate formation in the oxidation of the ambient mixture of VOCs.

\subsubsection{Using morning $\Sigma \mathrm{AN}$ rise to determine $\mathrm{RONO}_{2}$ yield and impact on $\mathrm{O}_{3}$ production}

Tropospheric ozone formation is governed by the coupled $\mathrm{RO}_{\mathrm{x}}$ and $\mathrm{NO}_{\mathrm{x}}$ catalytic cycles. Without radical sinks, typically two $\mathrm{O}_{3}$ molecules are produced for each time around the $\mathrm{RO}_{\mathrm{x}}$ radical cycle $\left(\mathrm{RO}_{2} \rightarrow \mathrm{RO} \rightarrow \mathrm{HO}_{2} \rightarrow \mathrm{OH} \rightarrow \mathrm{RO}_{2}\right)$, because this drives the $\mathrm{NO} \rightarrow \mathrm{NO}_{2} \rightarrow \mathrm{NO}$ cycle twice (Seinfeld and Pandis, 1998; Sect. 5.10). The radical sink (R2) occurs as a minor secondary channel in the $\mathrm{RO}_{2}+\mathrm{NO}$ reaction, the yield of which $(A=\mathrm{R} 2 /(\mathrm{R} 1+\mathrm{R} 2))$ depends on the structure of the initial VOC.

$\mathrm{RO}_{2}+\mathrm{NO} \rightarrow \mathrm{RO}+\mathrm{NO}_{2}$
$\mathrm{RO}_{2}+\mathrm{NO} \rightarrow \mathrm{RONO}_{2}$

Values of $A$ range from near zero for small hydrocarbons like methane to, e.g., $18 \%$ for $\alpha$-pinene (Atkinson and Arey, 2003). Because of the coupling of $\mathrm{RO}_{\mathrm{x}}$ and $\mathrm{NO}_{\mathrm{x}}$ cycles leading to ozone formation, $A$ can be determined empirically by comparing ozone production to alkyl nitrate production when losses (including mixing) of $\mathrm{O}_{3}$ and $\mathrm{RONO}_{2}$ can be neglected (Rosen et al., 2004; Perring et al., 2013):

$\frac{\Delta \mathrm{O}_{3}}{\Delta \Sigma \mathrm{ANs}} \approx \frac{2(1-A)}{A} \approx \frac{2}{A}$.

$A$ is the fractional yield of $\mathrm{RONO}_{2}$ from $\mathrm{RO}_{2}+\mathrm{NO}$ reactions. This analysis would yield a tight, linear correlation if the airmass contained a single reactive hydrocarbon and all radical losses were due to $\mathrm{RO}_{2}+\mathrm{NO}$. A caveat is that this yield estimate will incorporate any $\Sigma \mathrm{AN}$ losses that occur on

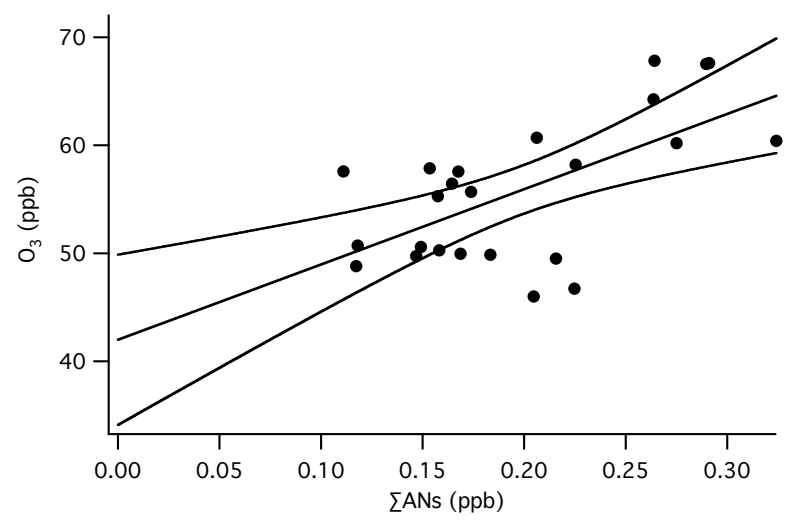

Fig. 6. Correlation plot of measured ambient $\mathrm{O}_{3}$ vs. $\Sigma$ ANs, for the $\approx 6$ days during the campaign when the TD-LIF was running in "3-gas" ambient mode, with standard linear regression including $95 \%$ confidence limits, slope $=70 \pm 38$. Only data from 12 noon6 p.m. LT are used (see text).

the six-hour timescale of the correlation plot. This may introduce variation in measured yields from different hydrocarbon mixtures and in different climates: especially if monoterpene nitrate products are multifunctional, and in a humid environment, losses could be significant and depress the apparent yield.

Figure 6 shows ambient $\mathrm{O}_{3}$ vs. $\Sigma$ ANs for the $\approx 6$-day period during which ambient $\Sigma$ ANs were separately measured (3-gas mode). Much of the variability is assumed to be due to the changing ambient mix of VOCs, but additional contributions to the variability may arise from mixing, especially during the morning breakup of the nighttime thermal inversion layer; hence, in order to omit periods where mixing or deposition of $\mathrm{O}_{3}$ compete with photochemical production, we include only data from noon to 18:00. The fitted slope of $70 \pm 38(=2 / A)$ implies an effective alkyl nitrate yield of $A=2.9+3.4 /-1.0 \%$, similar to a previously observed effective alkyl nitrate yield of $2.4 \%$ in an isoprene-dominated region (Horowitz et al., 2007). The major daytime VOCs at this site are $\mathrm{MBO}+$ isoprene (assumed to be dominantly MBO; Kim et al., 2010), with ten times lower concentration of monoterpenes. The $\mathrm{OH}$ rate constant with $\mathrm{MBO}$ is comparable to that with monoterpenes, but $\mathrm{MBO}$ is present at an order of magnitude larger concentration, so $\mathrm{RO}_{2}$ reactivity is assumed to be dominated by that from MBO. Measured organic nitrate yields from these precursors are available but not well constrained. Alvarado et al. (1999) report a nitrate yield of 5.2\% from MBO; Chan et al. (2009) report $10 \pm 4 \%$ yield. The ambient yield of $2.9 \%$ is lower than both MBO lab studies, suggesting either other VOCs contributing to $\mathrm{RO}_{2}$ chemistry or additional radical losses at the RoMBAS site.

This relatively small ambient alkyl nitrate yield implies that most of the $\mathrm{NO}_{\mathrm{x}}$ at the MFO site remains available for ozone production. In the absence of other chain-terminating reactions, the $\mathrm{RONO}_{2}$ yield of $2.9 \%$ would imply a $\mathrm{RO}_{\mathrm{x}}$ 
cycle length of 34; however, other reactions (e.g., $\mathrm{OH}+\mathrm{NO}_{2}$, $\mathrm{HO}_{2}+\mathrm{HO}_{2}$ ) are likely to contribute and reduce this cycle chain length.

\section{2 $\mathrm{NO}_{3}$ radical fate, nighttime organic nitrate and SOA production}

\subsubsection{Organic nitrate gas/aerosol partitioning}

Examining the $\mathrm{NO}_{\mathrm{y}}$ data from gas/aerosol mode, we find another interesting diurnal pattern. While total (gas + aerosolphase) $\Sigma$ PNs $+\Sigma$ ANs peaks during the day, aerosol-phaseonly $\Sigma$ PNs $+\Sigma$ ANs peaks during the night (bottom panel of Fig. 5). This can be seen most clearly in the diurnal cycle of the fraction of $\Sigma$ PNs $+\Sigma$ ANs in the aerosol phase (black trace, bottom panel of Fig. 5). Up to $30 \%$ of the organic nitrate is in the aerosol phase at night, but less than $10 \%$ during the day. Some of this may be due to repartitioning of semivolatile organic nitrates to the gas phase as temperature increases; however, we show in Sect. 3.2.3 that partitioning thermodynamics alone cannot account for the diurnal pattern observed in the bottom panel of Fig. 5 .

\subsubsection{Observed and calculated ambient $\mathrm{NO}_{3}$ and lifetime}

Early in the field campaign, the cavity ringdown $\mathrm{NO}_{3} / \mathrm{N}_{2} \mathrm{O}_{5}$ instrument was deployed to measure incanopy ambient concentrations for several nights (it was otherwise deployed to monitor oxidant exposure on a $\mathrm{NO}_{3}$ potential aerosol mass flowtube reactor, manuscript in preparation). On one of those nights, between 23 and 24 July 2011, $\mathrm{NO}_{3}$ and $\mathrm{N}_{2} \mathrm{O}_{5}$ displayed a sharp peak just after midnight (shown in the bottom panel of Fig. 7), coincident with a sharp peak in $\mathrm{NO}_{2}$ and during a period when $\mathrm{O}_{3}$ was anomalously elevated (55 ppb) until past midnight. In contrast, for most of the remainder of the ambient measurement period, no $\mathrm{NO}_{3}$ was detectable due to high levels of biogenic VOCs that provided a rapid $\mathrm{NO}_{3}$ sink.

We can use the peak measured $\left[\mathrm{NO}_{3}\right]=5 \mathrm{ppt}$, $\left[\mathrm{NO}_{2}\right]$ $=6.5 \mathrm{ppb}$, and $\left[\mathrm{O}_{3}\right]=55 \mathrm{ppb}$ to determine the lifetime of $\mathrm{NO}_{3}$ due to reactive losses, following the steady-state assumption derived in Eq. (8) of Brown et al. (2003a):

$\tau_{\mathrm{SS}}\left(\mathrm{NO}_{3}\right)=\frac{\left[\mathrm{NO}_{3}\right]}{k_{1}\left[\mathrm{O}_{3}\right]\left[\mathrm{NO}_{2}\right]} \approx k_{x}^{-1}$,

where $k_{1}$ is the rate constant for $\mathrm{O}_{3}+\mathrm{NO}_{2}$ and $k_{x}$ is the rate constant for reactive loss of $\mathrm{NO}_{3}$. The left-hand equality of this equation is the definition of the $\mathrm{NO}_{3}$ steady-state lifetime, and the right-hand approximation holds when $k_{x}$ is the only significant loss term, i.e., when sinks of $\mathrm{N}_{2} \mathrm{O}_{5}$ are negligible.

In this field campaign, the sinks of $\mathrm{N}_{2} \mathrm{O}_{5}$ indeed appear to be smaller than reactive loss of $\mathrm{NO}_{3}$. There are both homogeneous and heterogeneous reactions of $\mathrm{N}_{2} \mathrm{O}_{5}$ with
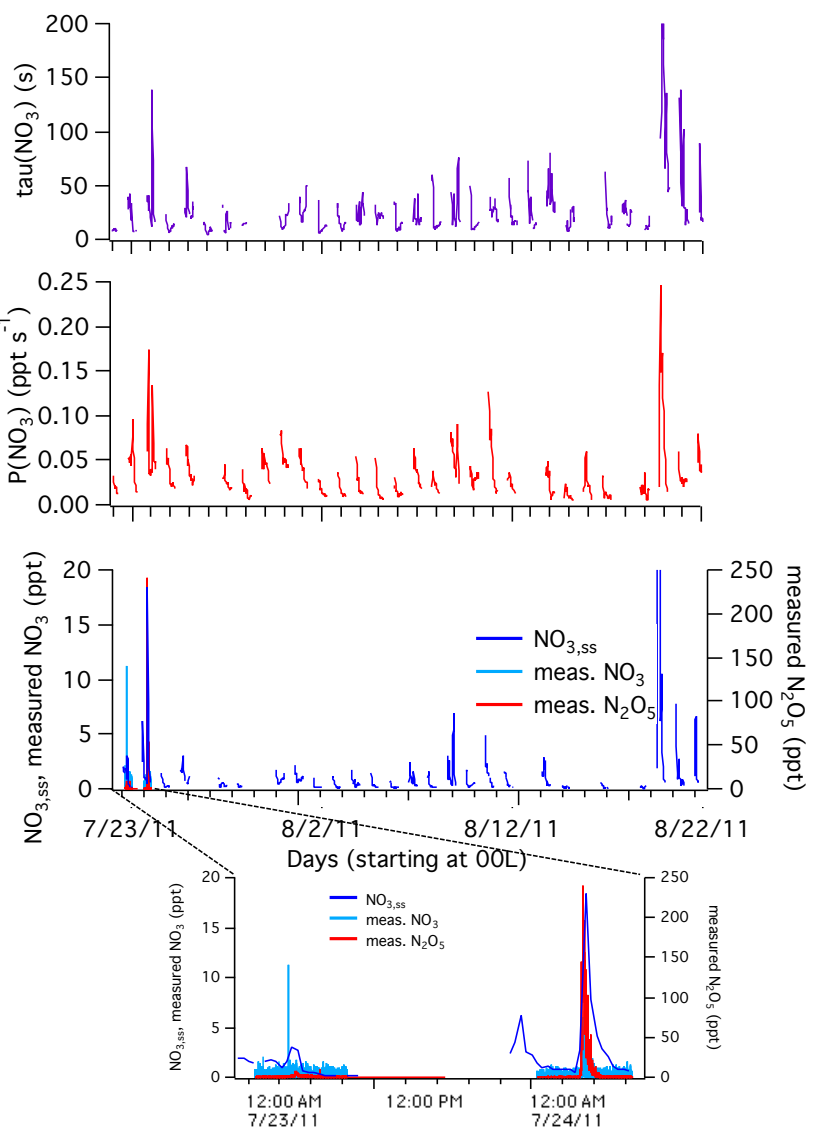

Fig. 7. Calculated lifetime based on BVOC reactive losses (top, purple), production rate from $\mathrm{NO}_{2}+\mathrm{O}_{3}$ (middle, red) and predicted steady-state concentration (lower, blue) of $\mathrm{NO}_{3}$ throughout the RoMBAS campaign, nights only. Lower panel also shows measured $\mathrm{NO}_{3}$ (aqua) and $\mathrm{N}_{2} \mathrm{O}_{5}$ (red) from two nights early in the campaign.

water, which have been examined extensively (e.g., Brown et al., 2009; Thornton et al., 2003; Wahner et al., 1998; Tuazon et al., 1983; Hjorth et al., 1987). However, the homogeneous $\mathrm{N}_{2} \mathrm{O}_{5}+\mathrm{H}_{2} \mathrm{O}$ rate constant is negligible for this dataset, especially since at $283 \mathrm{~K}$ absolute humidity is low (Brown et al., 2007; Crowley et al., 2011). We calculate relative rates of $\mathrm{N}_{2} \mathrm{O}_{5}$ heterogeneous uptake compared to $\mathrm{NO}_{3}$ reaction with BVOCs (dominated at night by monoterpenes), using typical nighttime monoterpene (MT), MBO, and sesquiterpene (SQT) concentrations (measured by PTR-ToF-MS) of $0.6 \mathrm{ppb}, 0.4 \mathrm{ppb}$, and $0.01 \mathrm{ppb}$, respectively, and the $\mathrm{N}_{2} \mathrm{O}_{5} / \mathrm{NO}_{3}$ ratio of 4.1. This ratio is calculated based on the $283 \mathrm{~K}$ equilibrium constant $\left(K_{\text {eq }}=\right.$ $\left[\mathrm{N}_{2} \mathrm{O}_{5}\right] /\left[\mathrm{NO}_{2}\right]\left[\mathrm{NO}_{3}\right]$ ) of $2.05 \times 10^{-10} \mathrm{~cm}^{3} \mathrm{molec}^{-1}$ (Sander et al., 2006) and $1 \mathrm{ppb} \mathrm{NO}_{2}$. The rate constant used for $\mathrm{NO}_{3}$ with monoterpenes is $6.1 \times 10^{-12} \mathrm{~cm}^{3} \mathrm{molec}^{-1} \mathrm{~s}^{-1}$, which is an average of the rate constants with $\alpha$-pinene, $\beta$-pinene, and $\Delta$-3-carene (Calvert et al., 2000), since they were present in roughly equal concentrations at RoMBAS 
(based on gas chromatology/mass spectrometry canister samples, not shown). For MBO, the $283 \mathrm{~K}$ rate constant of $1.1 \times 10^{-14} \mathrm{~cm}^{3} \mathrm{molec}^{-1} \mathrm{~s}^{-1}$ is used; for sesquiterpenes, we use the rate constant for $\beta$-caryophyllene of $1.9 \times$ $10^{-11} \mathrm{~cm}^{3} \mathrm{molec}^{-1} \mathrm{~s}^{-1}$. At the reported average concentrations, this gives an average $\mathrm{NO}_{3}$ lifetime $\left(\tau_{\mathrm{NO}_{3}, \mathrm{BVOC}}\right)$ of $14 \mathrm{~s}$, dominated by MT losses $\left(k_{i}[\mathrm{i}]\right.$ for MT: MBO : SQT is $1: 0.001: 0.05$ ).

$$
\begin{aligned}
& \tau_{\mathrm{NO}_{3}, \mathrm{BVOC}}=\frac{1}{k_{\mathrm{NO}_{3}+\mathrm{BVOC}}[\mathrm{BVOC}]} \\
& =\frac{1}{k_{\mathrm{NO}_{3}, \mathrm{MT}}[\mathrm{MT}]+k_{\mathrm{NO}_{3}, \mathrm{MBO}}[\mathrm{MBO}]+k_{\mathrm{NO}_{3}, \mathrm{SQT}}[\mathrm{SQT}]}
\end{aligned}
$$

The heterogeneous uptake of $\mathrm{N}_{2} \mathrm{O}_{5}$ onto aqueous particles depends on the uptake coefficient $(\gamma)$, molecular speed of $\mathrm{N}_{2} \mathrm{O}_{5}(v)$, and the aerosol surface area per volume (SA), parameterized as a first-order rate constant:

$k_{\text {het }}=\frac{\gamma v}{4} \mathrm{SA}$.

Measured uptake coefficients on liquid water range from 0.02 to 0.04 around $283 \mathrm{~K}$ (Sander et al., 2006); we use an upper limit value $\gamma=0.04$. At a typical observed (SEMS) nighttime aerosol surface area per air volume of $240 \mu \mathrm{m}^{2} \mathrm{~cm}^{-3}, \mathrm{~N}_{2} \mathrm{O}_{5}$ molecular speed of $2.3 \times 10^{4} \mathrm{~cm} \mathrm{~s}^{-1}$, this gives an average $\mathrm{N}_{2} \mathrm{O}_{5}$ lifetime $\left(\tau_{\mathrm{N}_{2} \mathrm{O}_{5} \text {, het }}\right)$ of $440 \mathrm{~s}$.

$\tau_{\mathrm{N}_{2} \mathrm{O}_{5}, \text { het }}=\frac{1}{k_{\text {het }}}$

Applying the $\mathrm{N}_{2} \mathrm{O}_{5} / \mathrm{NO}_{3}$ ratio of 4.1 and comparing to the $\tau_{\mathrm{NO}_{3}, \mathrm{BVOC}}$ to $\tau_{\mathrm{N}_{2} \mathrm{O}_{5} \text {, het }}$, this estimate suggests that the rate of $\mathrm{NO}_{3}$ with BVOC is 15 times faster than uptake of $\mathrm{N}_{2} \mathrm{O}_{5}$ to aqueous particles.

We apply the $\mathrm{NO}_{3}$ steady-state approximation (Eq. 5) to the case of the high- $\mathrm{NO}_{3}$ night (23-24 July), to compare the calculated lifetime of $\mathrm{NO}_{3}$ from steady state to that calculated from reactive loss via $k_{x}$. For the average ambient nighttime temperature of $\approx 283 \mathrm{~K}$, the rate constant of $\mathrm{O}_{3}$ with $\mathrm{NO}_{2}$ is $k_{1}=2.3 \times 10^{-17} \mathrm{~cm}^{3} \mathrm{molec}^{-1} \mathrm{~s}^{-1}$ (Atkinson et al., 2004). At the concentrations listed above, this gives $k_{x}^{-1}=\tau_{\mathrm{SS}}\left(\mathrm{NO}_{3}\right)=30 \mathrm{~s}$. Calculating the $\mathrm{NO}_{3}$ lifetime instead from the dominant MT loss $\left(k_{x}=k_{\mathrm{NO}_{3}, \mathrm{MT}}\right)$, at the observed average MT concentrations that night $(7 \mathrm{p}-5 \mathrm{a}$ local $)$ of $0.28 \mathrm{ppb}$, we find $\tau_{\mathrm{NO}_{3}, \mathrm{MT}}=29 \mathrm{~s}$, in excellent agreement with the steady-state prediction. Hence, $\mathrm{N}_{2} \mathrm{O}_{5}+\mathrm{NO}_{3}$ losses are in fact dominated by reactive loss of $\mathrm{NO}_{3}$ to biogenic VOCs, with a lifetime in the canopy on the order of seconds, making this a very efficient sink of both species.

Other than the period described above, no $\mathrm{NO}_{3}$ was observed on four additional nights the CRDS instrument was used to monitor ambient $\mathrm{NO}_{3}$ and $\mathrm{N}_{2} \mathrm{O}_{5}$, so it was subsequently deployed to make other measurements. In order to estimate ambient concentrations of $\mathrm{NO}_{3}$ at RoMBAS throughout the campaign, we can use Eq. (6) to determine an estimate of the $\mathrm{NO}_{3}$ lifetime, using the known mix, concentration time series, and $\mathrm{NO}_{3}$ rate constants of monoterpenes, sesquiterpenes, and MBO as described above. This calculation shows that maximum $\mathrm{NO}_{3}$ lifetimes throughout the campaign are consistently $<200$ s during the night. The top panel of Fig. 7 shows the result of this calculation, $\tau_{\mathrm{NO}_{3}}$, for the entire campaign. Daytime results have been omitted in this plot, since $\mathrm{NO}_{3}$ lifetime will be limited by photolysis and reaction with $\mathrm{NO}$ during the day.

We also calculate a full time series of the production rate of $\mathrm{NO}_{3}$ based on measured $\mathrm{O}_{3}, \mathrm{NO}_{2}$, and temperature $\left(\mathrm{P}\left(\mathrm{NO}_{3}\right)=k_{1}\left[\mathrm{O}_{3}\right]\left[\mathrm{NO}_{2}\right]\right)$, shown in the middle panel of Fig. 7. We predict production rates of up to $0.15-0.2 \mathrm{ppts}^{-1}$ $\left(0.5-0.7 \mathrm{ppbh}^{-1}\right)$, with peaks generally in the early evening when $\mathrm{NO}_{2}$ rise and $\mathrm{O}_{3}$ decline intersect (see Fig. 3). Combining these production and loss terms, we derive the time series shown in the bottom panel of Fig. 7, the predicted nighttime steady-state nitrate concentration:

$\mathrm{NO}_{3, \mathrm{SS}}=\frac{\mathrm{P}\left(\mathrm{NO}_{3}\right)}{\left(\tau_{\mathrm{NO}_{3}, \mathrm{BVOC}}\right)^{-1}}$.

Because $\mathrm{NO}_{3}$ will also be reactively lost to later generation oxidation products, this represents a conservative upper limit on the steady-state concentration of $\mathrm{NO}_{3}$. During the night of 24 July when a sustained peak $\mathrm{NO}_{3}$ of 5 ppt was measured, our steady-state calculation accurately predicts the timing of the peak, but overestimates its magnitude by almost a factor of 4 (predicted $\mathrm{NO}_{3}$ concentration was $18 \mathrm{ppt}$ ). For most of the campaign, the steady-state $\mathrm{NO}_{3}$ predicted in this way is significantly lower, near the detection limit of the CRDS instrument, so it may not be surprising that we did not detect it. Golz et al. (2001) also sought to measure $\mathrm{NO}_{3}$ using DOAS in a European forest and were unable to detect it.

\subsubsection{Evidence for $\mathrm{NO}_{3}$-initiated organic nitrate $\mathrm{SOA}$ production at night: predicted organic nitrate structures and modeled thermodynamics}

When $\mathrm{NO}_{3}$ oxidation of monoterpenes is modeled in the Leeds Master Chemical Mechanism (MCMv3.2; http://mcm. leeds.ac.uk/MCM; Jenkin et al., 1997; Saunders et al., 2003), the major organic nitrates produced by daytime (largely $\mathrm{OH}-$ initiated) and nighttime (largely $\mathrm{NO}_{3}$-initiated) oxidation are distinct (Fig. 8). We carried out two $12 \mathrm{~h}$ model runs with the chemical conditions observed at RoMBAS (temperature, $\left[\mathrm{O}_{3}\right],\left[\mathrm{NO}_{2}\right]$, [monoterpenes]) for daytime photochemistry and dark nighttime chemistry, and tracked the $>900$ products, identifying the top six organic nitrates in terms of peak concentration during that time period. Daytime simulations were run at $25^{\circ} \mathrm{C}$ and $30 \% \mathrm{RH}$, nighttime simulations at $10^{\circ} \mathrm{C}$ and $80 \% \mathrm{RH}$. For consistency, both were initiated with the same gas-phase concentrations of reactive precur-

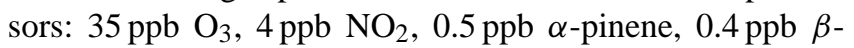
pinene, and $0.1 \mathrm{ppb}$ limonene $(\Delta-3$-carene is not yet in the 


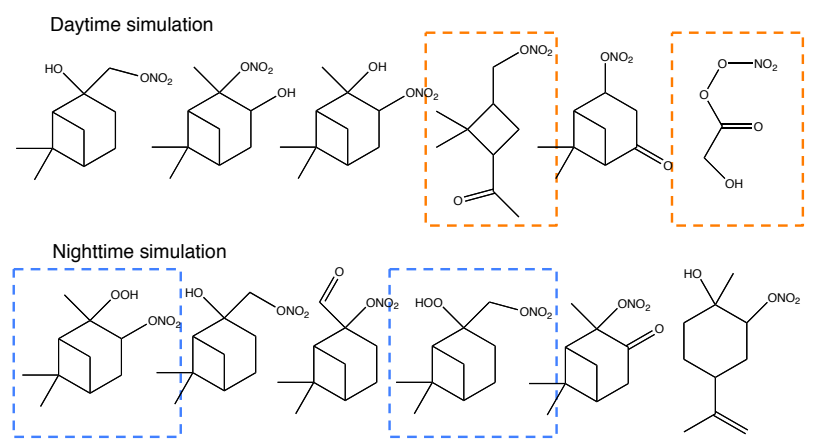

Fig. 8. Major organic nitrate oxidation products predicted by the MCM for daytime and nighttime simulations, initialized with observed monoterpene and oxidant concentrations at MFO. Structures are shown in order of peak concentration, with highest on the left. Outlined structures show the more volatile daytime nitrates (orange, predicted $p_{\text {vap }}>10^{-3}$ Torr; $C^{*}>10^{4} \mu \mathrm{gm}^{3}$ ) and less volatile nighttime nitrates (blue, predicted $p_{\text {vap }} \approx 10^{-5}$ Torr; $C^{*} \approx 100 \mu \mathrm{g} \mathrm{m}^{3}$ ).

MCM, and MBO was omitted because it is not expected to produce condensable products).

In both day- and nighttime cases, $\mathrm{C}_{10}$ hydroxynitrates are among the top products (Fig. 8). The remaining top organic nitrates show some differences, however: during the day, two fragmentation products are predicted (outlined in orange), which SIMPOLv.1 predicts to have higher volatility. The structure on the left, a $\mathrm{C}_{9}$ keto-nitrate, has a predicted vapor pressure of $5.7 \times 10^{-3}$ Torr at daytime average temperature of $298 \mathrm{~K}$, which is equivalent to a $C^{*}$ of $6.2 \times$ $10^{4} \mathrm{\mu g} \mathrm{m}^{3}$; the structure on the right, a multifunctional peroxynitrate produced glycolaldehyde, which has a predicted vapor pressure of $1.5 \times 10^{-3} \operatorname{Torr}\left(C^{*}=1.2 \times 10^{4} \mu \mathrm{g} \mathrm{m}^{3}\right)$. At night, in contrast, two hydroperoxynitrates are observed (outlined in blue), which are predicted to have lower volatility $\left(1.0 \times 10^{-5}\right.$ Torr at nighttime average temperature of $283 \mathrm{~K}$, $C^{*}=130 \mu \mathrm{g} \mathrm{m}^{3}$ ). Hence, accounting for day/night temperature differences observed during RoMBAS, nighttime $\mathrm{NO}_{3}$ produced organic nitrates have substantially lower volatility, consistent with the observation that a larger fraction of organic nitrates is in the aerosol phase at night.

Although daytime- and nighttime-produced organic nitrates are predicted to include distinct structures, some of the observed diurnal cycle in aerosol-phase fraction of nitrates (bottom panel of Fig. 5) may be explained by thermodynamics: as temperature cools at night, total organic nitrate repartitions to favor the condensed phase. We can test this by modeling the fraction in the aerosol phase for a series of organic nitrate structures deemed likely as monoterpene oxidation products. We employ the absorptive partitioning formalism introduced in Eq. (2) to predict background aerosoldependent (using AMS-measured organic aerosol) partitioning of hypothesized structures, using SIMPOLv.1 to predict
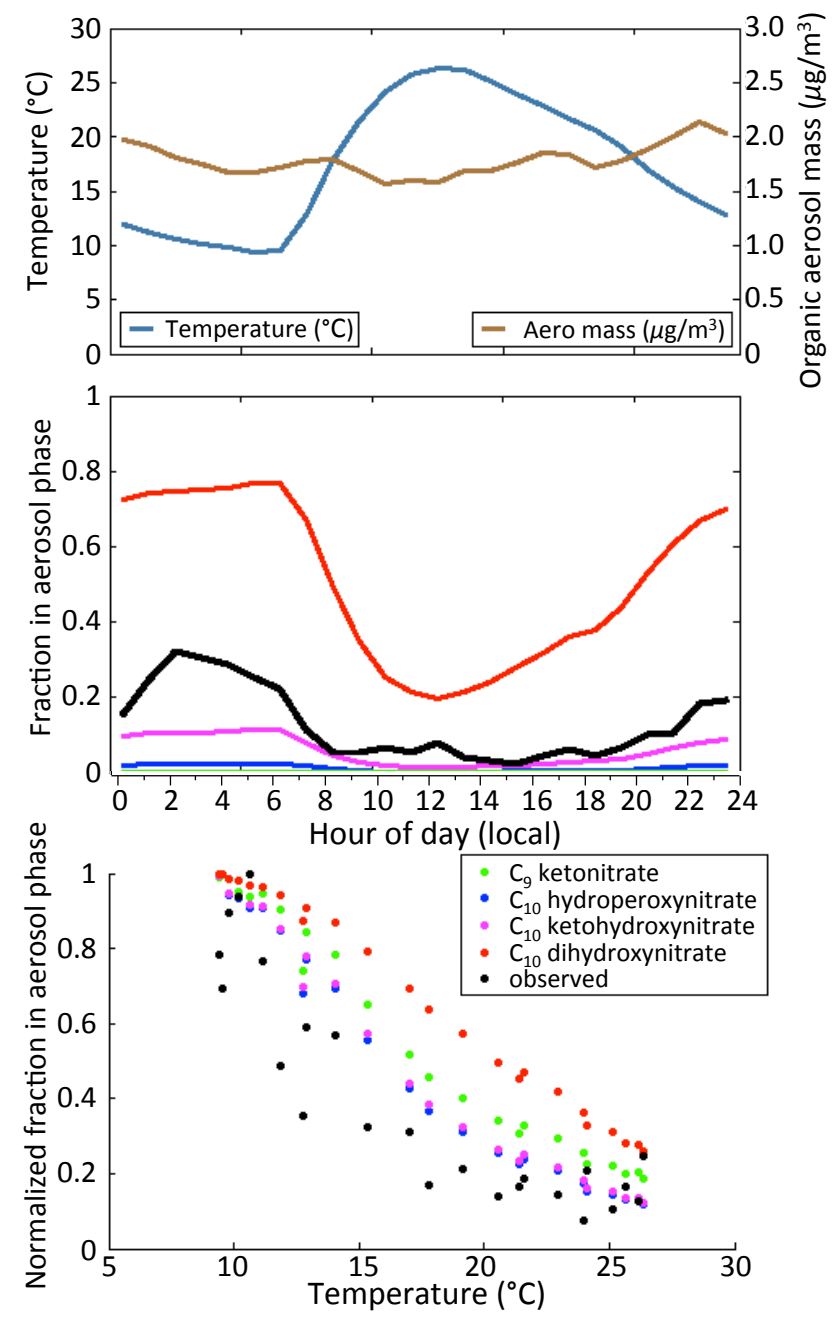

Fig. 9. Observed (black, same as in Fig. 5) and modeled fraction of organic nitrate in the aerosol phase over the diurnal cycle in temperature (blue) and background organic aerosol mass (measured by AMS, brown), based on calculated vapor pressures for a series of possible nitrate structures (indicated in legend). None of these structures can capture the observed dynamic range in aerosol fraction. Bottom panel shows aerosol fraction for the same series of molecules, demonstrating that the observed aerosol fraction does not fully scale with temperature as simple repartitioning of the same nitrates would predict. Data are normalized to peak fraction to facilitate comparison of the lineshapes.

the temperature-dependent vapor pressures of hypothesized structures. We calculate the average diurnal cycle in several multifunctional nitrates in this way (Fig. 9), using average diurnal cycles in temperature and ambient organic aerosol mass loading as inputs. These model predictions (colors) are shown with comparison to the observed aerosol nitrate fraction (black).

First, we note that neither daytime $\left(\mathrm{C}_{9}\right.$ keto-nitrate or $\left.\mathrm{PN}\right)$ nor nighttime $\left(\mathrm{C}_{10}\right.$ hydroperoxy-nitrate $) \mathrm{MCM}$-predicted products would partition appreciably to the aerosol phase 
in this simple model: the predicted volatilities are simply too high. As discussed above, Barley and McFiggans (2010) have pointed out that vapor pressure estimation methods differ widely; in a test of sensitivity of calculated OA formation to vapor pressure prediction, Barley and McFiggans observed that predicted multifunctional compounds were 1001000 times more volatile than needed to contribute significantly to OA.

We find a similar result here. In order to bracket the observed aerosol fraction, one or two additional functional groups must be added $\left(\mathrm{C}_{10}\right.$ keto-hydroxy-nitrate, $2.0 \times 10^{-6}$ Torr, $C^{*}=27 \mu \mathrm{g} \mathrm{m}^{3}$ at $283 \mathrm{~K}$; or $\mathrm{C}_{10}$ dihydroxynitrate, $8.0 \times 10^{-8}$ Torr, $C^{*}=1.0 \mu \mathrm{g} \mathrm{m}^{3}$ ). Alternatively, similarly low volatilities can be realized if the precursor BVOC is a sesquiterpene $\left(\mathrm{C}_{15}\right)$ with only two functional groups (e.g., $\mathrm{C}_{10}$ hydroperoxy-nitrate, $4.6 \times 10^{-8} \mathrm{Torr}, C^{*}=0.7 \mu \mathrm{g} \mathrm{m}{ }^{3}$ at $283 \mathrm{~K})$. Sesquiterpenes were measured at RoMBAS at much lower concentrations than monoterpenes (nighttime peak < $0.01 \mathrm{ppb}$, PTR-ToF-MS), but may have a disproportionate impact on aerosol formation because less functionalization is required to achieve lower volatility.

Furthermore, we observe that while the fraction in the aerosol phase falls in the range of these selected trifunctional molecular structures, none of these individual species captures the full dynamic range of aerosol fraction observed. As shown in the bottom panel of Fig. 9, the aerosol fraction is not simply a function of temperature: at the lowest temperatures the observed aerosol fraction is higher than the linear extrapolation that individual structures would predict. This again suggests that at least a subset of the organic nitrates contributing to aerosol during the day and night are in fact of different molecular structures with differing aggregate volatility. After condensation, these organic nitrates may also continue to evolve via condensed-phase reactions, resulting in a different aerosol composition than dictated by the initial condensing species. No such continuing transformations are treated in this simple thermodynamic model.

This apparent combination of thermodynamic repartitioning and different production mechanisms of organic nitrates contrasts with a recent study (Perraud et al., 2012), in which observed SOA formation from $\alpha$-pinene could only be explained by irreversible, kinetically limited uptake of organic nitrates onto aerosol. This difference may be explained by the BVOC precursor mix, if the mechanism is unique to $\alpha$ pinene, or by the elevated oxidant $\left(1.5 \mathrm{ppm} \mathrm{O}_{3}\right)$ and aerosol mass (30-2000 $\left.\mu \mathrm{g} \mathrm{m}^{3}\right)$ in those chamber experiments causing the SOA formation mechanism to be different than under ambient conditions at RoMBAS $\left(30 \mathrm{ppb} \mathrm{O}_{3}\right.$ and $2 \mu \mathrm{g} \mathrm{m}^{3} \mathrm{PM}_{1}$ at night).

\subsubsection{Further evidence for $\mathrm{NO}_{3}$-initiated organic nitrate SOA production at night: oxidant contributions}

We find further observational evidence that nighttime chemistry is dominated by $\mathrm{NO}_{3}$-initiated oxidation rather than

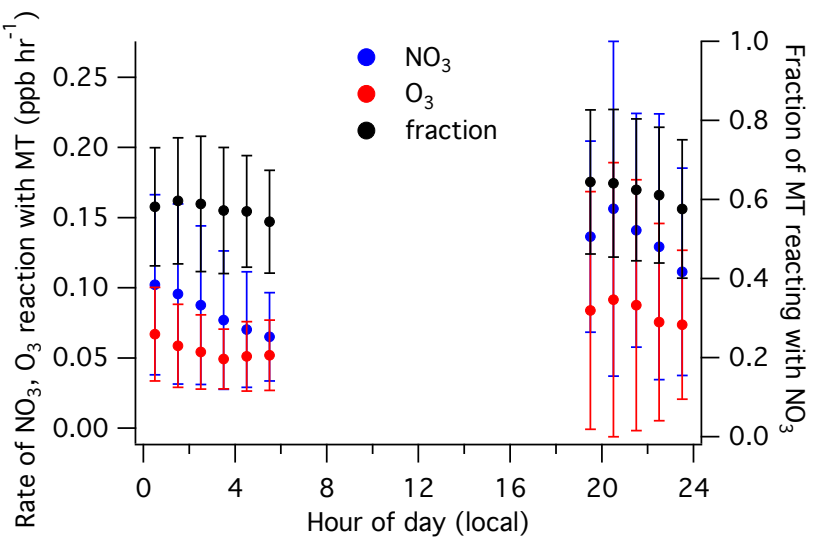

Fig. 10. Rates of reaction of $\mathrm{NO}_{3}$ and $\mathrm{O}_{3}$ with monoterpenes averaged for entire campaign, nighttime data only, using measured $\left[\mathrm{O}_{3}\right]$ and [monoterpenes], and using the production rate of $\mathrm{NO}_{3}\left(k_{1}\left[\mathrm{NO}_{2}\right]\left[\mathrm{O}_{3}\right]\right)$ to stand in for the rate of $\mathrm{NO}_{3}+\mathrm{MT}$, since it is assumed that every $\mathrm{NO}_{3}$ produced reacts with MT. Right axis: the fraction of total MT reactivity due to reactions with $\mathrm{NO}_{3}$ (black) suggests a greater role for $\mathrm{NO}_{3}$ than $\mathrm{O}_{3}$ as the initial oxidant in nighttime oxidation.

ozonolysis when we evaluate their relative rates for all of the campaign nighttime data (Fig. 10). We approximate the rate of $\mathrm{NO}_{3}+\mathrm{MT}$ as the rate of $\mathrm{NO}_{3}$ production $\left(P_{\mathrm{NO}_{3}}=k_{1}\left[\mathrm{NO}_{2}\right]\left[\mathrm{O}_{3}\right]\right)$, because we assume that at night nearly every $\mathrm{NO}_{3}$ produced is consumed by reaction with monoterpenes. We calculate the ozonolysis rate $\left(R_{\mathrm{O}_{3}+\mathrm{MT}}\right)$ as $k_{\mathrm{O}}\left[\mathrm{O}_{3}\right][\mathrm{MT}]$, where $k_{\mathrm{O}}=5.7 \times 10^{-17} \mathrm{~cm}^{3} \mathrm{molec}^{-1} \mathrm{~s}^{-1}$, the average of rates of ozonolysis of $\alpha$-pinene, $\beta$-pinene and $\Delta$-carene (Calvert et al., 2000), the three dominant monoterpenes observed at MFO. We calculate the fraction of monoterpenes oxidized by $\mathrm{NO}_{3}$ as $P_{\mathrm{NO}_{3}} /\left(P_{\mathrm{NO}_{3}}+R_{\mathrm{O}_{3}+\mathrm{MT}}\right)$ and find that throughout the campaign, $60 \% \pm 10 \%$ of the nighttime monoterpene reactivity goes via $\mathrm{NO}_{3}$.

\subsection{Aerosol organic nitrate concentrations derived from AMS measurements}

The nighttime peak in aerosol organic nitrate concentration is further corroborated by AMS measurements of this species (Fig. 11). Farmer et al. (2010) reported that due to fast thermal dissociation of organic nitrates prior to ionization, the AMS will quantify the nitrate moiety almost exclusively as $\mathrm{NO}^{+}$and $\mathrm{NO}_{2}^{+}$ions. Several groups have reported that the $\mathrm{NO}_{2}^{+} / \mathrm{NO}^{+}$ratios observed in AMS spectra for organic nitrates are typically 2-3 times lower than for $\mathrm{NH}_{4} \mathrm{NO}_{3}$ (Fry et al., 2009; Bruns et al., 2010; Farmer et al., 2010; Liu et al., 2012). Assuming these ratios are stable, the measured ratio can be used to separately quantify ammonium and organic nitrates as (Farmer et al., 2010)

$\mathrm{RONO}_{2, \text { frac }}=\frac{\left(R_{\text {ambient }}-R_{\mathrm{NH}_{4} \mathrm{NO}_{3}}\right)\left(1+R_{\mathrm{RONO}_{2}}\right)}{\left(R_{\mathrm{RONO}_{2}}-R_{\mathrm{NH}_{4} \mathrm{NO}_{3}}\right)\left(1+R_{\text {ambient }}\right)}$. 

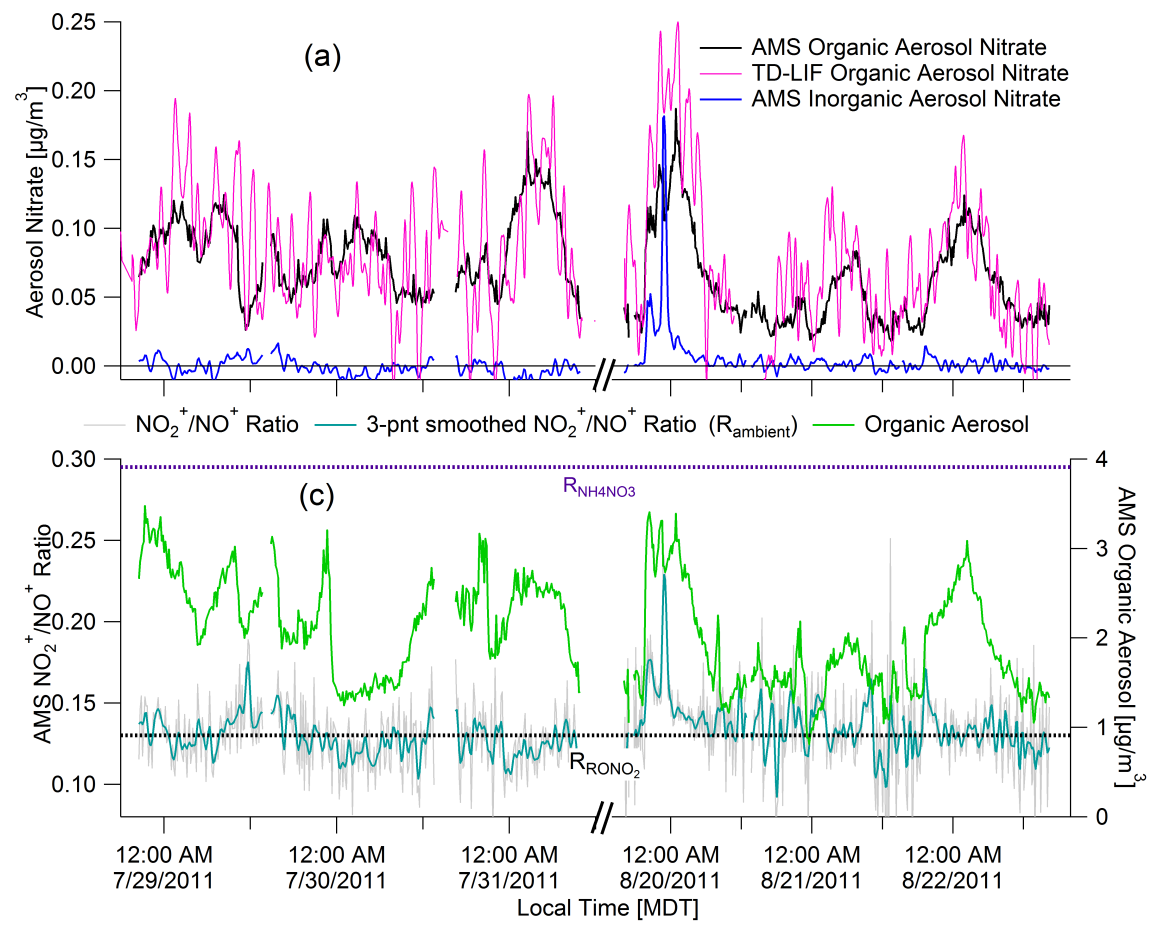
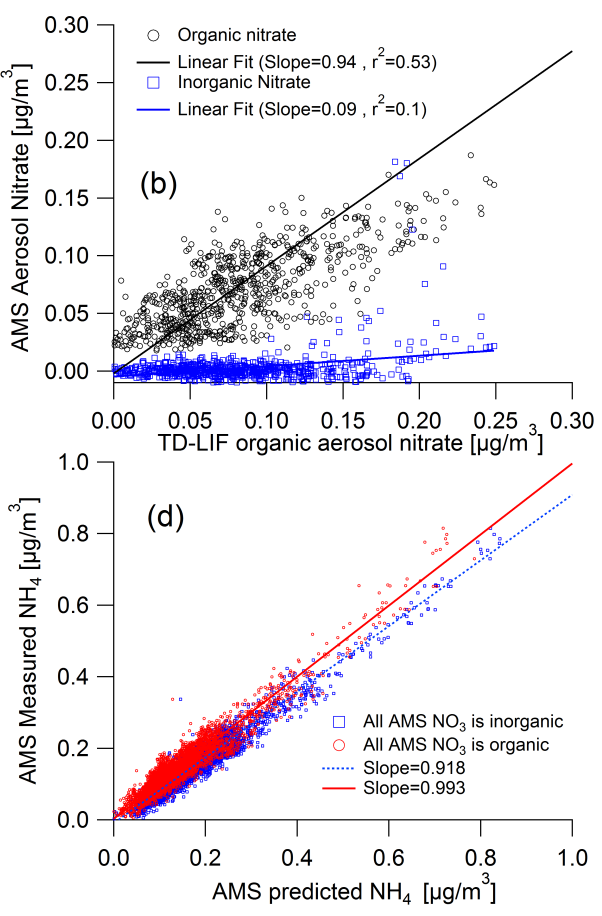

Fig. 11. (a) Concentration of AMS organic and inorganic nitrate, calculated based on the $\mathrm{NO}_{2}^{+} / \mathrm{NO}^{+}$field ratios and $R_{\mathrm{RONO}}=0.13$, compared to aerosol organic nitrate measurements with the TD-LIF system, for the six days the ambient measurements of both instruments overlapped during RoMBAS. (b) Scatter plot of calculated AMS organic and inorganic nitrate with TD-LIF aerosol organic nitrate. (c) Total organic aerosol mass as measured by the AMS, and $\mathrm{NO}_{2}^{+} / \mathrm{NO}^{+}\left(R_{\text {ambient }}\right)$ used to calculate organic nitrate fraction in (a). Also shown are the $\mathrm{NO}_{2}^{+} / \mathrm{NO}^{+}$ratio determined in calibration with inorganic nitrate as well as the estimated $R_{\mathrm{RONO}_{2}}$ ratio. A 3-point smoothed version of the ratio was used when calculating $\mathrm{RONO}_{2}$. (d) Cation vs. anion balance, evaluated by plotting measured AMS ammonium vs. predicted ammonium for two cases: assuming all AMS nitrate is inorganic and assuming it is all organic.

According to Eq. (10), $R_{\text {ambient }}$ (the ratio of $\mathrm{NO}_{2}^{+} / \mathrm{NO}^{+}$ in ambient data) can be used to calculate the fraction of organic nitrate, $\mathrm{RONO}_{2}$,frac, if both $R_{\mathrm{NH}_{4} \mathrm{NO}_{3}}$ (for the ammonium nitrate calibrant) and $R_{\mathrm{RONO}_{2}}$ (measured or assumed average $\mathrm{NO}_{2}^{+} / \mathrm{NO}^{+}$for organic nitrates) are known. It should be noted that this expression only applies if $\mathrm{NH}_{4} \mathrm{NO}_{3}$ is the solely important inorganic nitrate in the submicron mode, since other nitrate salts have different fragmentation ratios. However, as noted above, it is unlikely that reacted dust or sea salt contributed significantly to the submicron aerosol during RoMBAS.

Both $R_{\mathrm{NH}_{4} \mathrm{NO}_{3}}$ and $R_{\mathrm{RONO}_{2}}$ depend on the particular AMS instrument and AMS tuning; hence they need to be determined at the same instrument settings as $R_{\text {ambient }}$. While $R_{\mathrm{NH}_{4} \mathrm{NO}_{3}}$ can be determined from the routine in-field calibrations, estimating $R_{\mathrm{RONO}_{2}}$ is more difficult as there is some variability in the ratios found for pure organic nitrates (Farmer et al., 2010), and standards for the specific organic nitrates important at a field location are typically not available at the time of the field study. One possible way to circumvent this issue is to use the observation that $R_{\mathrm{NH}_{4} \mathrm{NO}_{3}}$ and $R_{\mathrm{RONO}_{2}}$ typically co-vary proportionally between instruments. Based on that observation, we derive field values for
$R_{\mathrm{RONO}_{2}}$ based on previous laboratory measurements of the "ratio of ratios" $\chi$ :

$\chi=\frac{R_{\mathrm{NH}_{4} \mathrm{NO}_{3}}}{R_{\mathrm{RONO}_{2}}}$.

Based on the calibrations reported by Farmer et al. (2010), we calculate a value for $\chi$ of $2.25 \pm 0.35$. Using the (very constant) $R_{\mathrm{NH}_{4} \mathrm{NO}_{3}}$ of $0.295 \pm 0.005$ measured throughout the in-field IE calibrations, this would result in $R_{\mathrm{RONO}_{2}}=0.13 \pm$ 0.02 .

Figure 11c shows $R_{\text {ambient }}$ for ambient data for the six days where the AMS and the TD-LIF ambient aerosol datasets overlap. $R_{\text {ambient }}$ is quite constant within the noise at $\approx 0.13$, with the exception of a brief spike around midnight of 20 August. This implies that the fraction of total nitrate that is organic was essentially constant, with no diurnal cycle, except for a few brief inorganic nitrate episodes such as on 20 August. Given the very different night and day chemistry, it seems unlikely that this fraction would stay constant, unless it happens to correspond to $100 \%$ organic nitrate, which is consistent with the $R_{\mathrm{RONO}_{2}}$ value derived above.

Another piece of evidence that supports the dominance of organic nitrates in the submicron nitrate at this location is 
the anion vs. cation balance. A linear regression of measured AMS ammonium vs. predicted, assuming that all measured nitrate is inorganic, leads to a negative intercept and a slope of less than 1 (Fig. 11d; slope $=0.92$ ). The deviation of the slope from 1 is substantially larger than the $2 \%$ observed for $\mathrm{NH}_{4} \mathrm{NO}_{3}$ calibrations. Such a deviation is normally associated with partially acidic sulfate, but in those cases the deviation typically varies substantially in time (e.g., Zhang et al., 2007), and that would also be expected here given the large variability of $\mathrm{SO}_{2}$ (Fig. 4). The slope can also be due to mistakenly assuming $\mathrm{RONO}_{2}$ to be inorganic nitrate (Farmer et al., 2010). If we instead exclude all of the aerosol nitrate from the neutralization calculation, the slope becomes very close to 1 (0.99) and the negative intercept disappears. As can be inferred from the tightness of the scatter plot, for most of the campaign this ratio was very constant. While this could reflect an aerosol of fairly constant free acidity, that would be highly unusual for such a long time period. Hence, the most likely explanation is that the anions were fully neutralized and thus most of the nitrate was organic.

Calculated AMS organic nitrate concentrations are compared with the TD-LIF data in Fig. 11a. The overall agreement between the two organic nitrate measurements, both in amplitude and time dependence, is very good. Figure 11b compares AMS organic and inorganic nitrates with the TDLIF aerosol nitrate. As expected, there is little correlation of TD-LIF nitrate with AMS inorganic nitrate $\left(r^{2}=0.1\right)$, while the correlation with AMS organic nitrate correlation is fair $\left(r^{2}=0.53\right)$, despite separate inlets, the low concentrations involved, and the difference in analytical methods. Both datasets were averaged to a longer timebase (i.e., longer than the $10 \mathrm{~min}$ original database). The slope for the resampled data, 1.16, seems to indicate a slightly lower AMS response, but is well within the stated accuracies for the instruments ( $30 \%$ for the AMS, $25 \%$ for the TD-LIF). The dominance of aerosol organic nitrate over the inorganic form at this location contrasts with polluted urban locations such as Riverside, CA, where the aerosol nitrate is dominated by the inorganic form (Farmer et al., 2010).

The concentrations of aerosol organic nitrate concentrations shown in Fig. 11a for both instruments only quantify the $\mathrm{NO}_{3}$ functional group and do not reflect the actual mass of organic molecules containing nitrate functional groups that are present in the aerosol (since both techniques detect the nitrate functional group after it has dissociated from the organic parent structure). Estimating a total mass for the organic molecules containing nitrate groups is difficult, since the average molecular mass of the organic species per $\mathrm{NO}_{3}$ group is needed for this calculation. Assuming that the $\mathrm{C}_{10^{-}}$ keto-hydroxy-nitrate as shown in Fig. 9 is a representative organic nitrate molecule, the molecular weight of the molecule minus the nitrate group is $168 \mathrm{~g} \mathrm{~mol}^{-1}, 2.7$ times larger than the mass of the nitrate group. For the periods considered here, that implies a concentration of $\approx 0.2-0.5 \mu \mathrm{g} \mathrm{m}^{-3}$ of organic species with nitrate groups, representing $6-20 \%$ of the to- tal organic aerosol mass at a given time. As first reported by Farmer et al. (2010), this also has implications for the O/C and $\mathrm{N} / \mathrm{C}$ ratios that the AMS reports, since the default analysis algorithm used for field studies assumes that only $\mathrm{CHO}$, $\mathrm{CHN}$, and $\mathrm{CHON}$ ions are organic and all of the $\mathrm{NO}_{\mathrm{x}}^{+}$ions are assigned to the "nitrate" species. For RoMBAS, including nitrate from $\mathrm{RONO}_{2}$ in the calculation of organic N/C would increase by 0.013 on average (up to 0.025 at night and about 0.009 during the day), while typical AMS N/C values which do not include organic nitrate are $\approx 0.01-0.02$ (e.g., Hayes et al., 2012; Docherty et al., 2011). Likewise, O/C ratios would be enhanced 0.03 on average, with spikes of up to 0.07 at night, resulting in about a $5 \%$ increase for the campaign average.

\subsection{Estimated alkyl nitrate production rate, daytime vs. nighttime}

Finally, we wish to put the nighttime production of alkyl nitrates into context with the total nitrate production. We use both our empirically determined net daytime yield of $\mathrm{RONO}_{2}$ from $\mathrm{RO}_{2}+\mathrm{NO}$ reactions $A=2.9 \%$ (Sect. 3.1.4) as well as higher literature values from chamber studies, to determine two estimates of daytime production rates of organic nitrates from $\mathrm{OH}$-initiated reactions followed by $\mathrm{RO}_{2}+\mathrm{NO}$, for comparison to nighttime $\mathrm{NO}_{3}$-initiated chemistry.

We calculate the daytime production rate of alkyl nitrates as

$P_{\text {day }}=\left(k_{\mathrm{OH}_{1}}[\mathrm{OH}][\mathrm{MT}] \alpha_{\mathrm{MT}}+k_{\mathrm{OH}_{2}}[\mathrm{OH}][\mathrm{MBO}] \alpha_{\mathrm{MBO}}\right) F_{\mathrm{RO}_{2}+\mathrm{NO}}$

where $k_{\mathrm{OH}_{1}}=7.4 \times 10^{-11} \mathrm{~cm}^{3} \mathrm{molec}^{-1} \mathrm{~s}^{-1}$ (Calvert et al., 2000 ) is the average of the rate constants for $\mathrm{OH}$ reaction with $\beta$-pinene, $\alpha$-pinene, and $\Delta$-carene at this temperature (these three dominant monoterpenes are present in approximately equal concentrations at RoMBAS), and $k_{\mathrm{OH}_{2}}=$ $6.5 \times 10^{-11} \mathrm{~cm}^{3} \mathrm{molec}^{-1} \mathrm{~s}^{-1}$ (293 K, Rudich et al., 1995) is the rate constant of $\mathrm{OH}$ with $\mathrm{MBO}$. The values for $\alpha_{\mathrm{MT}}$ and $\alpha_{\mathrm{MBO}}$ are either chosen to both be equal to $A$, the empirically determined branching ratio of alkyl nitrate production from $\mathrm{RO}_{2}+\mathrm{NO}$ reactions, or to be equal to values from literature chamber studies (23\% for monoterpenes, Perring et al., 2013; and $7 \%$ for MBO, Alvarado et al., 1999; Chan et al., 2009). The former production rate is lower by about a factor of 5. $F_{\mathrm{RO}_{2}+\mathrm{NO}}$ is the fraction of $\mathrm{RO}_{2}$ radicals that react with $\mathrm{NO}$ rather than other $\mathrm{RO}_{2}$ or $\mathrm{HO}_{2}$.

The calculation of $F_{\mathrm{RO} 2+\mathrm{NO}}$ is based on diurnal $\mathrm{RO}_{2}$ and $\mathrm{HO}_{2}$ data with calculated $\mathrm{NO}$ steady-state concentrations:

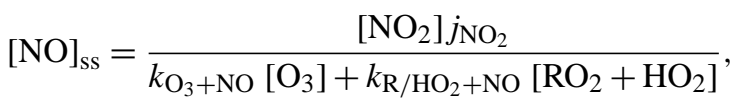

where $j_{\mathrm{NO}_{2}}$ is the photolysis rate of $\mathrm{NO}_{2}, k_{\mathrm{O}_{3}+\mathrm{NO}}=1.4 \times$ $10^{-12} \exp (-1310 / T) \mathrm{cm}^{3} \mathrm{molec}^{-1} \mathrm{~s}^{-1}$ and $k_{\mathrm{R} / \mathrm{HO}_{2}+\mathrm{NO}=}=$ $7.9 \times 10^{-12} \mathrm{~cm}^{3} \mathrm{molec}^{-1} \mathrm{~s}^{-1}$, which is the average of rate constants of $\mathrm{HO}_{2}+\mathrm{NO}$ and $\mathrm{CH}_{3} \mathrm{O}_{2}+\mathrm{NO}$ (Sander et al., 2006), using instantaneous measured temperature, $\left[\mathrm{O}_{3}\right]$, 
$\left[\mathrm{RO}_{2}\right],\left[\mathrm{NO}_{2}\right]$ and $\left[\mathrm{HO}_{2}\right]$. Typical daytime $\left[\mathrm{HO}_{2}\right]$ peaked midday at $100 \mathrm{ppt} ;\left[\mathrm{RO}_{2}\right]$ was $45-55 \mathrm{ppt}$ throughout the day, and [NO] peaked at $80 \mathrm{ppt}$ at 8:30 and 14:30 and was > $40 \mathrm{ppt}$ throughout the day. To determine the relative rates of $\mathrm{RO}_{2}+\mathrm{NO}$ reactions, we use rate constants for $\mathrm{CH}_{3} \mathrm{O}_{2}$ (Atkinson et al., 2004). We use the $\mathrm{CH}_{3} \mathrm{O}_{2}$ rate constants because those reactions have been well characterized; however, since they are for a smaller $\mathrm{RO}_{2}$ than the ambient mix, this likely introduces some error.

Nighttime production rate of alkyl nitrates is calculated as

$P_{\text {night }}=\left[\mathrm{NO}_{3}\right]\left(k_{\mathrm{MT}}[\mathrm{MT}] Y_{\mathrm{MT}}+k_{\mathrm{MBO}}[\mathrm{MBO}] Y_{\mathrm{MBO}}\right)$,

where $k_{i}$ and $Y_{i}$ are $\mathrm{NO}_{3}$ rate constants and organic nitrate yields, respectively, from monoterpenes and MBO. Again, we use $6.1 \times 10^{-12} \mathrm{~cm}^{3} \mathrm{molec}^{-1} \mathrm{~s}^{-1}$ for the $\mathrm{NO}_{3}+$ monoterpene rate, the average of rate constants with $\alpha$-pinene, $\beta$-pinene, and $\Delta$-3-carene (Calvert et al., 2000). The rate constant for $\mathrm{NO}_{3}$ with $\mathrm{MBO}$ is $1.1 \times 10^{-14} \mathrm{~cm}^{3} \mathrm{molec}^{-1} \mathrm{~s}^{-1}$ (Rudich et al., 1996) at $283 \mathrm{~K}$. Yields of organic nitrates from MT and MBO are taken to be $45 \%$ (Fry et al., 2009; measured nitrate yield for $\beta$-pinene) and $13 \%$ (Fantechi et al., 1998), respectively. The few measurements of organic nitrate yields from $\left[\mathrm{NO}_{3}\right]+\mathrm{BVOC}$ that have been made are reviewed in Atkinson and Arey (2003), and span the range of $14 \%$ for $\alpha$-pinene to $66 \%$ for $\Delta-3$ carene, making this $\beta$-pinene figure a reasonable average behavior for the monoterpenes present at RoMBAS.

Rollins et al. (2012) also recently assessed aerosol organic nitrate yield from $\mathrm{NO}_{3}$-initiated SOA formation, in Bakersfield, California, an urban site in the agricultural San Joaquin Valley with much higher $\mathrm{NO}_{2}, \mathrm{O}_{3}$, and biogenic VOC concentrations, and particle loading. At that site, BVOC concentrations are so high that $\mathrm{RONO}_{2}$ production is limited by $\mathrm{NO}_{3}$ production via $\mathrm{NO}_{2}+\mathrm{O}_{3}$, which proceeds at typical rates of 1-2 $\mathrm{ppbh}^{-1}$ (Rollins et al., 2012). Significantly lower organic nitrate production is observed at RoMBAS $\left(0.05 \mathrm{ppbh}^{-1}\right)$, due to much lower pollutant concentrations, but at both sites the resulting contribution of $\mathrm{RONO}_{2}$ to organic aerosol loading is substantial.

A comparison of daytime (OH-initiated) and nighttime $\left(\mathrm{NO}_{3}\right.$-initiated) rates of alkyl nitrate production is shown in Fig. 12, showing a diurnal cycle that indicates the rates are comparable in magnitude, with the nighttime production rate falling between the two estimates of daytime organonitrate production. The difference in these two daytime production rate estimates suggests that $\mathrm{MBO}$ and monoterpenes are not the only sinks of $\mathrm{OH}$ at this site: since the observed overall $A$ is lower than the yield for $\mathrm{MBO}$, it is likely that at this site, substantial $\mathrm{OH}$ loss goes to $\mathrm{RO}_{2}$ which have a low or $0 \%$ yield of organic nitrate, bringing the overall yield down. For example, the $\mathrm{OH}$ oxidation of first-generation products of MBO oxidation may be important. Note also that this analysis omits contributions from ozone, which may contribute to alkyl nitrate formation both during the day and night, but which we cannot constrain.

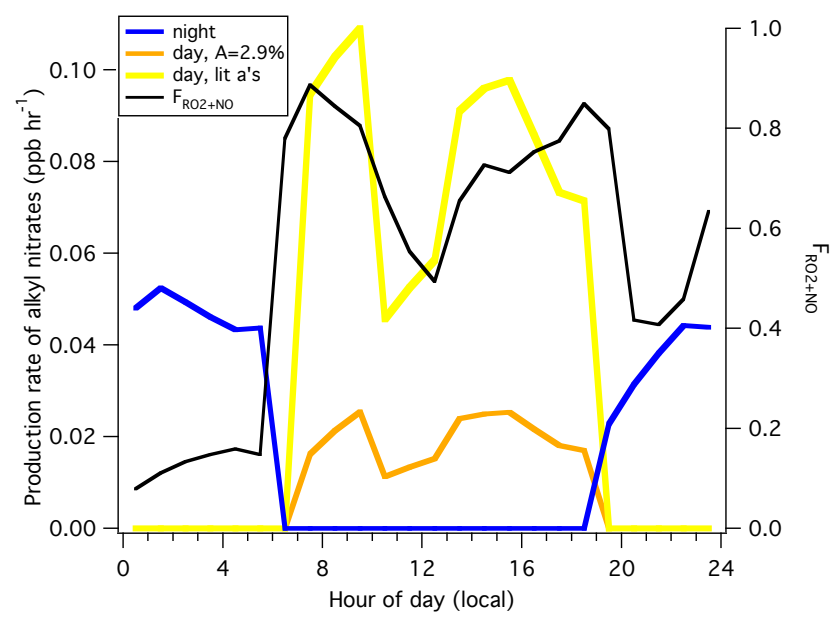

Fig. 12. Calculated rates of production of organic nitrates for daytime $\mathrm{OH}$-initiated (orange/yellow) and nighttime $\mathrm{NO}_{3}$-initiated (blue) mechanisms. The fraction of $\mathrm{RO}_{2}$ radicals that react with $\mathrm{NO}$ $\left(F_{\mathrm{RO}_{2}+\mathrm{NO}}\right.$, black) ranges from $\approx 40 \%-90 \%$ during the day. The daytime production of organic nitrates is calculated using the observed $A$ of $2.9 \%$ (orange) and, alternately, using literature chamber organic nitrate yields of $23 \%$ for monoterpenes and $7 \%$ for $\mathrm{MBO}$ (yellow).

These production rates are both likely underestimates since they consider only first-generation oxidation chemistry initiated by $\mathrm{OH}$ or $\mathrm{NO}_{3}$, and omit other VOC precursors that may contribute to additional organic nitrate production, e.g., sesquiterpenes. We note further that the empirically derived $A$, the daytime organic nitrate branching ratio, implicitly includes any fast chemical losses of daytime $\mathrm{RONO}_{2}$, including potentially rapid hydrolysis in the aerosol phase (Liu et al., 2012), while the nighttime source calculation is the gross formation rate, with any nighttime $\mathrm{RONO}_{2}$ losses unaccounted for. Based on structural differences - daytime organic nitrates are derived from shorter-chain hydrocarbons and are thus likely to have more oxidized functional groups per carbon and hence be more hydroscopic - we anticipate wet deposition losses to be faster for daytime than nighttime $\mathrm{RONO}_{2}$. Thus, we believe it is more important that these losses are incorporated for the daytime $\mathrm{RONO}_{2}$ production rate, and we expect the error in net nighttime production rate due to omission of chemical losses to be relatively small.

Because this organic nitrate production is occurring in very different volumes during the day (afternoon boundary layer height of $800-1500 \mathrm{~m}$, radiosonde measurements) vs. night (shallow nocturnal boundary layer height of order 50 to $90 \mathrm{~m}$ ), the total mass of organic nitrate produced during the day is likely to be larger if the $\mathrm{NO}_{\mathrm{x}}$ or BVOC level aloft during the night is significantly smaller than that at the surface. Nevertheless, the lower-volatility nighttime organic nitrates produced in the shallower boundary layer lead to a peak in observed aerosol organic nitrate at night. This is consistent with the hypothesis that nighttime $\mathrm{NO}_{3}$-initiated chemistry 
is a dominant source of aerosol organic nitrate surface concentrations in the Colorado front range.

\section{Conclusions}

Substantial morning organic nitrate production is observed at a pine forest site with $\mathrm{NO}_{2}$ mixing ratios in the $0.5-3 \mathrm{ppb}$ range in the Colorado front range, attributed to BVOC reactions with oxidants present in the urban outflow of Denver and Colorado Springs. The fraction of this organic nitrate in the aerosol phase is highest during nighttime, suggesting that nighttime $\mathrm{NO}_{3}$-initiated chemistry produces more condensable organic nitrates, in addition to thermal repartitioning of all organic nitrates. Comparison of TD-LIF and AMS measurements of organic nitrates shows that aerosol nitrate signal at this site is dominated by organic nitrate, and the aerosol organic nitrate concentrations measured by these two distinct instruments agree very well. Despite the distance from urban centers, $\mathrm{NO}_{3}$-initiated oxidation is observed to be an important reaction at this site, which is assumed to be representative of forested areas within the Colorado front range foothills. $\mathrm{NO}_{3}$ radical is responsible for the majority of nighttime monoterpene losses, and contributes substantially to organic aerosol loading.

Acknowledgements. J. L. Fry gratefully acknowledges sabbatical support from the Cooperative Institute for Research in Environmental Science (CIRES) and the National Center for Atmospheric Research Visiting Scholars Program. The work was supported in part by NOAA's Atmospheric Chemistry and Climate Program. K. J. Zarzana was supported by a NASA grant, NNX09AE12G. Measurements conducted by the University of Innsbruck were supported by the Austrian Science Fund (FWF):[L518]; L. Kaser is a recipient of a DOC-fFORTE-fellowship of the Austrian Academy of Sciences at the Institute of Ion Physics and Applied Physics. A. Hodzic Roux was supported by NSF and by the US DOE grant DE-SC0006711. P. Campuzano-Jost, D. A. Day, and J. L. Jimenez were supported by NSF ATM-0919189. We thank the Cohen research group (UC Berkeley) for the generous instrument loan of the TD-LIF and remote support, especially Drew Rollins, Paul Wooldridge, Kyung-Eun Min, and Ellie Browne. We thank Carsten Warneke, Jim Roberts, Martin Graus, Jim Smith, Peter Harley, and the BEACHON-RoMBAS field campaign team for helpful discussions. We thank the BEACHON project at NCAR (sponsored by NSF) for logistics support during the campaign, and Mike Ryan and the US Forest Service for allowing us to use the Manitou Experimental Forest.

Edited by: J. Rinne

\section{References}

Alvarado, A., Tuazon, E., Aschmann, S., Arey, J., and Atkinson, R.: Products and mechanisms of the gas-phase reactions of $\mathrm{OH}$ radicals and O-3 with 2-methyl-3-buten-2-ol, Atmos. Environ., 33, 2893-2905, 1999.

Aneja, V., Kim, D.-S., Das, M., and Hartsell, B.: Measurements and analysis of reactive nitrogen species in the rural troposphere of southeast United States: Southern Oxidant Study site SONIA, Atmos. Environ., 30, 649-659, 1996.

Atkinson, R. and Arey, J.: Gas-phase tropospheric chemistry of biogenic volatile organic compounds: a review, Atmos. Environ., 37, Suppl. 2, 197-219, doi:10.1016/S1352-2310(03)00391-1, 2003.

Atkinson, R., Baulch, D. L., Cox, R. A., Crowley, J. N., Hampson, R. F., Hynes, R. G., Jenkin, M. E., Rossi, M. J., and Troe, J.: Evaluated kinetic and photochemical data for atmospheric chemistry: Volume $\mathrm{I}-$ gas phase reactions of $\mathrm{O}_{\mathrm{x}}, \mathrm{HO}_{\mathrm{x}}, \mathrm{NO}_{\mathrm{x}}$ and $\mathrm{SO}_{\mathrm{x}}$ species, Atmos. Chem. Phys., 4, 1461-1738, doi:10.5194/acp-41461-2004, 2004.

Barley, M. H. and McFiggans, G.: The critical assessment of vapour pressure estimation methods for use in modelling the formation of atmospheric organic aerosol, Atmos. Chem. Phys., 10, 749767, doi:10.5194/acp-10-749-2010, 2010.

Beaver, M. R., Clair, J. M. St., Paulot, F., Spencer, K. M., Crounse, J. D., LaFranchi, B. W., Min, K. E., Pusede, S. E., Wooldridge, P. J., Schade, G. W., Park, C., Cohen, R. C., and Wennberg, P. O.: Importance of biogenic precursors to the budget of organic nitrates: observations of multifunctional organic nitrates by CIMS and TD-LIF during BEARPEX 2009, Atmos. Chem. Phys., 12, 5773-5785, doi:10.5194/acp-12-5773-2012, 2012.

Brown, S. S., Stark, H., Ciciora, S., and Ravishankara, A. R.: Insitu measurement of atmospheric $\mathrm{NO}_{3}$ and $\mathrm{N}_{2} \mathrm{O}_{5}$ via cavity ringdown spectroscopy, Geophys. Res. Lett., 28, 3227-3230, 2001.

Brown, S. S., Stark, H., and Ravishankara, A. R.: Applicability of the steady state approximation to the interpretation of atmospheric observations of $\mathrm{NO}_{3}$ and $\mathrm{N}_{2} \mathrm{O}_{5}$, J. Geophys. Res., 108, 4539, doi:10.1029/2003JD003407, 2003a.

Brown, S. S., Stark, H., Ryerson, T., William, E., Nicks, D., Trainer, M., Fehsenfeld, F., and Ravishankara, A. R.: Nitrogen oxides in the nocturnal boundary layer: Simultaneous in situ measurements of $\mathrm{NO}_{3}, \mathrm{~N}_{2} \mathrm{O}_{5}, \mathrm{NO}_{2}$, $\mathrm{NO}$, and $\mathrm{O}_{3}$, J. Geophys. Res., 108, 4299, doi:10.1029/2002jd002917, 2003 b.

Brown, S. S., Dubé, W. P., Osthoff, H. D., Wolfe, D. E., Angevine, W. M., and Ravishankara, A. R.: High resolution vertical distributions of $\mathrm{NO}_{3}$ and $\mathrm{N}_{2} \mathrm{O}_{5}$ through the nocturnal boundary layer, Atmos. Chem. Phys., 7, 139-149, doi:10.5194/acp-7139-2007, 2007

Brown, S. S., Dube, W., Fuchs, H., Ryerson, T., Wollny, A., Brock, C., Bahreini, R., Middlebrook, A., Neuman, J., Atlas, E., Roberts, J., Osthoff, H., Trainer, M., Fehsenfeld, F., and Ravishankara, A. R.: Reactive uptake coefficients for $\mathrm{N}_{2} \mathrm{O}_{5}$ determined from aircraft measurements during the Second Texas Air Quality Study: comparison to current model parameterizations, J. Geophys. Res., 114, doi:10.1029/2008JD011679, 2009.

Bruns, E., Perraud, V., Zelenyuk, A., Ezell, M., Johnson, S., Yu, Y., Imre, D., Finlayson-Pitts, B., and Alexander, M.: Comparison of FTIR and particle mass spectrometry for the measurement of particulate organic nitrates, Environ. Sci. Technol., 44, 1056-1061, doi:10.1021/es9029864, 2010. 
Calvert, J., Atkinson, J., Kerr, J., Madronich, S., Moortgat, G. K., Wallington, T., and Yarwood, G.: Mechanisms of the Atmospheric Oxidation of the Alkenes, Oxford University Press, New York, NY, USA, 83 pp., 2000.

Capouet, M. and Müller, J.-F.: A group contribution method for estimating the vapour pressures of $\alpha$-pinene oxidation products, Atmos. Chem. Phys., 6, 1455-1467, doi:10.5194/acp-6-1455-2006, 2006.

Cappellin, L., Biasioli, F., Granitto, P. M., Schuhfried, E., Soukoulis, C., Costa, F., Maerk, T. D., and Gasperi, F.: On data analysis in PTR-TOF-MS: From raw spectra to data mining, Sensor. Actuator. B-Chem., 155, 183-190, 2011.

Carter, W.: Documentation of the SAPRC-99 Chemical Mechanism for VOC Reactivity Assessment, Draft report to the California Air Resources Board, Contracts 92329 and 95308, available at: http://www.cert.ucr.edu/ carter/absts.htm (last access: November 2012), 2000.

Chan, A., Galloway, M., Kwan, A., Chhabra, P., Keutsch, F., Wennberg, P., Flagan, R., and Seinfeld, J.: Photooxidation of 2-methyl-3-buten-2-ol (MBO) as a potential source of secondary organic aerosol, Environ. Sci. Technol., 43, 4647-4652, doi:10.1021/es802560w, 2009.

Crowley, J. N., Thieser, J., Tang, M. J., Schuster, G., Bozem, H., Beygi, Z. H., Fischer, H., Diesch, J.-M., Drewnick, F., Borrmann, S., Song, W., Yassaa, N., Williams, J., Pöhler, D., Platt, U., and Lelieveld, J.: Variable lifetimes and loss mechanisms for $\mathrm{NO}_{3}$ and $\mathrm{N}_{2} \mathrm{O}_{5}$ during the DOMINO campaign: contrasts between marine, urban and continental air, Atmos. Chem. Phys., 11, 10853-10870, doi:10.5194/acp-11-10853-2011, 2011.

Day, D. A., Wooldridge, P. J., Dillon, M., Thornton, J. A., and Cohen, R. C.: A thermal dissociation laser-induced fluorescence instrument for in situ detection of $\mathrm{NO}_{2}$, peroxy nitrates, alkyl nitrates, and $\mathrm{HNO}_{3}$, J. Geophys. Res., 107, doi:10.1029/2001JD000779, 2002.

de Gouw, J. A., Middlebrook, A. M., Warneke, C., Goldan, P. D., Kuster, W. C., Roberts, J. M., Fehsenfeld, F. C., Worsnop, D. R., Canagaratna, M. R., Pszenny, A. A. P., Keene, W. C., Marchewka, M., Bertman, S. B., and Bates, T. S.: Budget of organic carbon in a polluted atmosphere: results from the New England Air Quality Study in 2002, J. Geophys. Res.-Atmos., 110, D16305, doi:10.1029/2004JD005623, 2005.

DeCarlo, P., Kimmerl, J., Trimborn, A., Northway, M., Jayne, J., Aiken, A., Gonin, M., Fuhrer, K., Horvath, T., Docherty, K., Worsnop, D., and Jimenez, J.: Field-Deployable, HighResolution, Time-of-Flight Aerosol Mass Spectrometer, Anal. Chem., 78, 8281-8289, 2006.

Docherty, K. S., Aiken, A. C., Huffman, J. A., Ulbrich, I. M., DeCarlo, P. F., Sueper, D., Worsnop, D. R., Snyder, D. C., Peltier, R. E., Weber, R. J., Grover, B. D., Eatough, D. J., Williams, B. J., Goldstein, A. H., Ziemann, P. J., and Jimenez, J. L.: The 2005 Study of Organic Aerosols at Riverside (SOAR-1): instrumental intercomparisons and fine particle composition, Atmos. Chem. Phys., 11, 12387-12420, doi:10.5194/acp-11-12387-2011, 2011.

Donahue, N. M., Robinson, A. L., Stanier, C. O., and Pandis, S. N.: Coupled partitioning, dilution, and chemical aging of semivolatile organics, Environ. Sci. Technol., 40, 2635-2643, doi:10.1021/es052297c, 2006.
Dzepina, K., Volkamer, R. M., Madronich, S., Tulet, P., Ulbrich, I. M., Zhang, Q., Cappa, C. D., Ziemann, P. J., and Jimenez, J. L.: Evaluation of recently-proposed secondary organic aerosol models for a case study in Mexico City, Atmos. Chem. Phys., 9, 5681-5709, doi:10.5194/acp-9-5681-2009, 2009.

Fantechi, G., Jensen, N., Hjorth, J., and Peeters, J.: Mechanistic studies of the atmospheric oxidation of methyl butenol by $\mathrm{OH}$ radicals, ozone, and $\mathrm{NO}_{3}$ radicals, Atmos. Environ., 32, 35473556, 1998.

Farina, S., Adams, P., and Pandis, S.: Modeling global secondary organic aerosol formation and processing with the volatility basis set: Implications for anthropogenic secondary organic aerosol, J. Geophys. Res., 115, D09202, doi:10.1029/2009JD013046, 2010.

Farmer, D., Matsunaga, A., Docherty, K., Surratt, J., Seinfeld, J., Ziemann, P., and Jimenez, J.: Response of an aerosol mass spectrometer to organonitrates and organosulfates and implications for atmospheric chemistry, P. Natl. Acad. Sci. USA, 107, 66706675, doi:10.1073/pnas.0912340107, 2010.

Fraser, M. P., Cass, G. R., and Simoneit, B. R. T.: Gas-phase and particle-phase organic compounds emitted from motor vehicle traffic in a Los Angeles roadway tunnel, Environ. Sci. Technol., 32, 2051-2060, doi:10.1021/es970916e, 1998.

Fry, J. L., Kiendler-Scharr, A., Rollins, A. W., Wooldridge, P. J., Brown, S. S., Fuchs, H., Dubé, W., Mensah, A., dal Maso, M., Tillmann, R., Dorn, H.-P., Brauers, T., and Cohen, R. C.: Organic nitrate and secondary organic aerosol yield from $\mathrm{NO}_{3}$ oxidation of $\beta$-pinene evaluated using a gas-phase kinetics/aerosol partitioning model, Atmos. Chem. Phys., 9, 14311449, doi:10.5194/acp-9-1431-2009, 2009.

Fry, J. L., Kiendler-Scharr, A., Rollins, A. W., Brauers, T., Brown, S. S., Dorn, H.-P., Dubé, W. P., Fuchs, H., Mensah, A., Rohrer, F., Tillmann, R., Wahner, A., Wooldridge, P. J., and Cohen, R. C.: SOA from limonene: role of $\mathrm{NO}_{3}$ in its generation and degradation, Atmos. Chem. Phys., 11, 3879-3894, doi:10.5194/acp-11-3879-2011, 2011.

Fuchs, H., Dube, W., Ciciora, S., and Brown, S.: Determination of inlet transmission and conversion efficiencies for in situ measurements of the nocturnal nitrogen oxides, $\mathrm{NO}_{3}, \mathrm{~N}_{2} \mathrm{O}_{5}$ and $\mathrm{NO}_{2}$, via pulsed cavity ring-down spectroscopy, Anal. Chem., 80, 60106017, 2008.

Fuentes, J. D., Wang, D., Bowling, D. R., Potosnak, M., Monson, R. K., Goliff, W. S., and Stockwell, W. R.: Biogenic hydrocarbon chemistry within and above a mixed deciduous forest, J. Atmos. Chem., 56, 165-185, 2007.

Geyer, A., Alicke, B., Konrad, S., Schmitz, T., Stutz, J., and Platt, U.: Chemistry and oxidation capacity of the nitrate radical in the continental boundary layer near Berlin, J. Geophys. Res., 106, 8013-8025, doi:10.1029/2000JD900681, 2001.

Golz, C., Senzig, J., and Platt, U.: $\mathrm{NO}_{3}$-initiated oxidation of biogenic hydrocarbons, Chemosphere - Global Change Sci., 3, 339352, doi:10.1016/S1465-9972(01)00015-0, 2001.

Graus, M., Mueller, M., and Hansel, A.: High Resolution PTR-TOF: Quantification and Formula Confirmation of VOC in Real Time, J. Am. Soc. Mass Spectr., 21, 1037-1044, doi:10.1016/j.jasms.2010.02.006, 2010.

Grell, G., Peckham, S., Schmitz, R., McKeen, S., Frost, G., Skamarock, W., and Eder, B.: Fully coupled online chemistry within the WRF model, Atmos. Environ., 39, 6957-6975, 
doi:10.1016/j.atmosenv.2005.04.027, 2005.

Guenther, A., Karl, T., Harley, P., Wiedinmyer, C., Palmer, P. I., and Geron, C.: Estimates of global terrestrial isoprene emissions using MEGAN (Model of Emissions of Gases and Aerosols from Nature), Atmos. Chem. Phys., 6, 3181-3210, doi:10.5194/acp-63181-2006, 2006.

Harley, R., Hannigan, M., and Cass, G.: Respeciation of organic gas emissions and the detection of excess unburned gasoline in the atmosphere, Environ. Sci. Technol., 26, 2395-2408, 1992.

Hayes, P., Ortega, A., Cubison, M., Hu, W., Toohey, D., Flynn, J., Lefer, B., Grossberg, N., Alvarez, S., Rappenglück, B., Taylor, J., Allan, J., Holloway, J., Gilman, J., Kuster, W., de Gouw, J., Massoli, P., Zhang, X., Liu, J., Weber, R., Corrigan, A., Russell, L., Zhao, Y., Cliff, S., Isaacman, G., Worton, D., Kreisberg, N., Hering, S., Goldstein, A., Thalman, R., Waxman, E., Volkamer, R., Lin, Y., Surratt, J., Kleindienst, T., Offenberg, J., Froyd, K., Dusanter, S., Griffith, S., Stevens, P., Brioude, J., Angevine, W., and Jimenez, J. L.: Aerosol composition and sources in Los Angeles during the 2010 CalNex Campaign, J. Geophys. Res.-Atmos., doi:10.1002/jgrd.50530, in press, 2012.

Heald, C. L., Jacob, D. J., Park, R. J., Russell, L. M., Huebert, B. J., Seinfeld, J. H., Liao, H., and Weber, R. J.: A large organic aerosol source in the free troposphere missing from current models, Geophys. Res. Lett., 32, L18809, doi:10.1029/2005GL023831, 2005.

Hjorth, J., Ottobrini, G., Cappellani, F., and Restelli, G.: A Fourier transform infrared study of the rate constant of the homogeneous gas-phase reaction nitrogen oxide $\left(\mathrm{N}_{2} \mathrm{O}_{5}\right)+$ water and determination of absolute infrared band intensities of $\mathrm{N}_{2} \mathrm{O}_{5}$ and nitric acid, J. Phys. Chem., 91, 1565-1568, doi:10.1021/j100290a055, 1987.

Hodzic, A., Jimenez, J. L., Madronich, S., Canagaratna, M. R., DeCarlo, P. F., Kleinman, L., and Fast, J.: Modeling organic aerosols in a megacity: potential contribution of semi-volatile and intermediate volatility primary organic compounds to secondary organic aerosol formation, Atmos. Chem. Phys., 10, 5491-5514, doi:10.5194/acp-10-5491-2010, 2010.

Hodzic, A., Wiedinmyer, C., Salcedo, D., and Jimenez, J.: Impact of trash burning on air quality in Mexico City, Environ. Sci. Technol., 46, 4950-4957, doi:10.1021/es203954r, 2012.

Hodzic, A., Gochis, D., Chen, F., et al.: Meteorological conditions, emissions and transport of pollutants over the Rocky Mountains region during the 2011 BEACHON-ROMBAS field study, in preparation, 2013.

Horowitz, L. W., Fiore, A. M., Milly, G. P., Cohen, R. C., Perring, A., Wooldridge, P. J., Hess, P. G., Emmons, L. K., and Lamarque, J.-F.: Observational constraints on the chemistry of isoprene nitrates over the eastern United States, J. Geophys. Res., 112, D12S08, doi:10.1029/2006JD007747, 2007.

Hoyle, C. R., Boy, M., Donahue, N. M., Fry, J. L., Glasius, M., Guenther, A., Hallar, A. G., Huff Hartz, K., Petters, M. D., Petäjä, T., Rosenoern, T., and Sullivan, A. P.: A review of the anthropogenic influence on biogenic secondary organic aerosol, Atmos. Chem. Phys., 11, 321-343, doi:10.5194/acp-11-321-2011, 2011.

Jenkin, M., Saunders, S., and Pilling, M.: The tropospheric degradation of volatile organic compounds: a protocol for mechanism development, Atmos. Environ., 31, 81-104, doi:10.1016/S13522310(96)00105-7, 1997.
Jimenez, J. L., Canagaratna, M. R., Donahue, N. M., Prevot, A. S. H., Zhang, Q., Kroll, J. H., DeCarlo, P. F., Allan, J. D., Coe, H., Ng, N. L., Aiken, A. C., Docherty, K. S., Ulbrich, I. M., Grieshop, A. P., Robinson, A. L., Duplissy, J., Smith, J. D., Wilson, K. R., Lanz, V. A., Hueglin, C., Sun, Y. L., Tian, J., Laaksonen, A., Raatikainen, T., Rautiainen, J., Vaattovaara, P., Ehn, M., Kulmala, M., Tomlinson, J. M., Collins, D. R., Cubison, M. J., E., Dunlea, J., Huffman, J. A., Onasch, T. B., Alfarra, M. R., Williams, P. I., Bower, K., Kondo, Y., Schneider, J., Drewnick, F., Borrmann, S., Weimer, S., Demerjian, K., Salcedo, D., Cottrell, L., Griffin, R., Takami, A., Miyoshi, T., Hatakeyama, S., Shimono, A., Sun, J. Y., Zhang, Y. M., Dzepina, K., Kimmel, J. R., Sueper, D., Jayne, J. T., Herndon, S. C., Trimborn, A. M., Williams, L. R., Wood, E. C., Middlebrook, A. M., Kolb, C. E., Baltensperger, U., and Worsnop, D. R.: Evolution of organic aerosols in the atmosphere, Science, 1525-1529, doi:10.1126/science.1180353, 2009.

Jordan, A., Haidacher, S., Hanel, G., Hartungen, E., Mark, L., Seehauser, H., Schottkowsky, R., Sulzer, P., and Mark, T.: A high resolution and high sensitivity proton-transfer-reaction time-offlight mass spectrometer (PTR-TOF-MS), Int. J. Mass Spectrom., 286, 122-128, doi:10.1016/j.ijms.2009.07.005, 2009.

Kaser, L., Karl, T., Schnitzhofer, R., Graus, M., Herdlinger-Blatt, I. S., DiGangi, J. P., Sive, B., Turnipseed, A., Hornbrook, R. S., Zheng, W., Flocke, F. M., Guenther, A., Keutsch, F. N., Apel, E., and Hansel, A.: Comparison of different real time VOC measurement techniques in a ponderosa pine forest, Atmos. Chem. Phys., 13, 2893-2906, doi:10.5194/acp-13-2893-2013, 2013.

Kim, S., Karl, T., Guenther, A., Tyndall, G., Orlando, J., Harley, P., Rasmussen, R., and Apel, E.: Emissions and ambient distributions of Biogenic Volatile Organic Compounds (BVOC) in a ponderosa pine ecosystem: interpretation of PTR-MS mass spectra, Atmos. Chem. Phys., 10, 1759-1771, doi:10.5194/acp-10-17592010, 2010.

Kim, S., Wolfe, G. M., Mauldin, L., Cantrell, C., Guenther, A., Karl, T., Turnipseed, A., Greenberg, J., Hall, S. R., Ullmann, K., Apel, E., Hornbrook, R., Kajii, Y., Nakashima, Y., Keutsch, F. N., DiGangi, J. P., Henry, S. B., Kaser, L., Schnitzhofer, R., Graus, M., Hansel, A., Zheng, W., and Flocke, F. F.: Evaluation of $\mathrm{HO}_{\mathrm{x}}$ sources and cycling using measurement-constrained model calculations in a 2-methyl-3-butene-2-ol (MBO) and monoterpene (MT) dominated ecosystem, Atmos. Chem. Phys., 13, 20312044, doi:10.5194/acp-13-2031-2013, 2013.

Lee-Taylor, J., Madronich, S., Aumont, B., Baker, A., Camredon, M., Hodzic, A., Tyndall, G. S., Apel, E., and Zaveri, R. A.: Explicit modeling of organic chemistry and secondary organic aerosol partitioning for Mexico City and its outflow plume, Atmos. Chem. Phys., 11, 13219-13241, doi:10.5194/acp-1113219-2011, 2011.

Liu, S., Shilling, J., Song, C., Hiranuma, N., Zaveri, R., and Russell, L.: Hydrolysis of organonitrate functional groups in aerosol particles, Aerosol. Sci. Tech., 46, 1359-1369, doi:10.1080/02786826.2012.716175, 2012.

Middlebrook, A., Bahreini, R., Jimenez, J., and Canagaratna, M.: Evaluation of composition-dependent collection efficiencies for the aerodyne aerosol mass spectrometer using field data, Aerosol. Sci. Tech., 46, 258-271, doi:10.1080/02786826.2011.620041, 2012. 
Müller, M., Graus, M., Ruuskanen, T. M., Schnitzhofer, R., Bamberger, I., Kaser, L., Titzmann, T., Hörtnagl, L., Wohlfahrt, G., Karl, T., and Hansel, A.: First eddy covariance flux measurements by PTR-TOF, Atmos. Meas. Tech., 3, 387-395, doi:10.5194/amt-3-387-2010, 2010.

Pankow, J. F.: An absorption-model of gas-particle partitioning of organic-compounds in the atmosphere, Atmos. Environ., 28, 185-188, 1994.

Pankow, J. F. and Asher, W. E.: SIMPOL.1: a simple group contribution method for predicting vapor pressures and enthalpies of vaporization of multifunctional organic compounds, Atmos. Chem. Phys., 8, 2773-2796, doi:10.5194/acp-8-27732008, 2008.

Perraud, V., Bruns, E. A., Ezell, M. J., Johnson, S. N., Yu, Y., Alexander, M. L., Zelenyuk, A., Imre, D., Chang, W. L., Dabdub, D., Pankow, J. F., and Finlayson-Pitts, B. J.: Nonequilibrium atmospheric secondary organic aerosol formation and growth, P. Natl. Acad. Sci. USA, 108, 2836-2841, doi:10.1073/pnas.1119909109, 2012.

Perring, A. E., Wisthaler, A., Graus, M., Wooldridge, P. J., Lockwood, A. L., Mielke, L. H., Shepson, P. B., Hansel, A., and Cohen, R. C.: A product study of the isoprene $+\mathrm{NO}_{3}$ reaction, Atmos. Chem. Phys., 9, 4945-4956, doi:10.5194/acp-9-4945-2009, 2009.

Perring, A. E., Pusede, S. E., and Cohen, R. C.: An Observational Perspective on the Atmospheric Impacts of Alkyl and Multifunctional Nitrates on Ozone and Secondary Organic Aerosol, Chem. Rev., 113, 5848-5870, doi:10.1021/cr300520x, 2013.

Pye, H. O. T., Chan, A. W. H., Barkley, M. P., and Seinfeld, J. H.: Global modeling of organic aerosol: the importance of reactive nitrogen $\left(\mathrm{NO}_{\mathrm{x}}\right.$ and $\left.\mathrm{NO}_{3}\right)$, Atmos. Chem. Phys., 10, 1126111276, doi:10.5194/acp-10-11261-2010, 2010.

Roberts, J., Fehsenfeld, F., Liu, S., Bollinger, M., Hahn, C., Albritton, D., and Sievers, R.: Measurements of aromatic hydrocarbon ratios and $\mathrm{NO}_{\mathrm{x}}$ concentrations in the rural troposphere - observation of air mass photochemical aging and $\mathrm{NO}_{\mathrm{x}}$ removal, Atmos. Environ., 18, 2421-2432, 1984.

Robinson, A. L., Donahue, N. M., Shrivastava, M. K., Weitkamp, E. A., Sage, A. M., Grieshop, A. P., Lane, T. E., Pierce, J. R., and Pandis, S. N.: Rethinking organic aerosols: semivolatile emissions and photochemical aging, Science, 315, 1259-1262, doi:10.1126/science.1133061, 2007.

Rollins, A. W., Smith, J., Wilson, K., and Cohen, R. C.: Real time in situ detection of organic nitrates in atmospheric aerosols, Environ. Sci. Technol., 44, 5540-5545, doi:10.1021/es100926x, 2010

Rollins, A. W., Browne, E. C., Min, K.-E., Pusede, S. E., Wooldridge, P. J., Gentner, D. R., Goldstein, A. H., Liu, S., Day, D. A., Russell, L. M., and Cohen, R. C.: Evidence for $\mathrm{NO}_{\mathrm{x}}$ control over nighttime SOA formation, Science, 337, 1210-1212, doi:10.1126/science.1221520, 2012.

Rosen, R. S., Wood, E. C., Wooldridge, P. J., Thornton, J. A., Day, D. A., Kuster, W., Williams, E. J., Jobson, B. T., and Cohen, R. C.: Observations of total alkyl nitrates during Texas Air Quality Study 2000: implications for $\mathrm{O}_{3}$ and alkyl nitrate photochemistry, J. Geophys. Res., 109, D07303, doi:10.1029/2003JD004227, 2004.

Rudich, Y., Talukdar, R. K., Burkholder, J. B., and Ravishankara, A. R.: The reaction of methyl butenol with $\mathrm{OH}$ radical: mecha- nism and atmospheric implications, J. Phys. Chem., 99, 1218812194, 1995.

Rudich, Y., Talukdar, R. K., Fox, R. W., and Ravishankara, A. R.: Rate coefficients for reactions of $\mathrm{NO}_{3}$ with a few olefins and oxygenated olefins, J. Phys. Chem., 100, 5374-5381, 1996.

Sander, S. P., Friedl, R. R., Golden, D. M., kurylo, M. J., Moortgat, G. K., Keller-Rudek, H., Wine, P. H., Ravishankara, A. R., Kolb, C. E., Molina, M. J., Finlayson-Pitts, B. J., and Huie, R. E.: Chemical Kinetics and Photochemical Data for Use in Atmospheric Studies, Evaluation Number 15, 2006.

Saunders, S. M., Jenkin, M. E., Derwent, R. G., and Pilling, M. J.: Protocol for the development of the Master Chemical Mechanism, MCM v3 (Part A): tropospheric degradation of nonaromatic volatile organic compounds, Atmos. Chem. Phys., 3, 161-180, doi:10.5194/acp-3-161-2003, 2003.

Schauer, J. J., Kleeman, M. J., Cass, G. R., and Simoneit, B. R. T.: Measurement of emissions from air pollution sources. 5. $\mathrm{C}_{1}-\mathrm{C}_{32}$ organic compounds from gasolinepowered motor vehicles, Environ. Sci. Technol., 36, 1169-1180, doi:10.1021/es0108077, 2002.

Seinfeld, J. H. and Pandis, S. N.: Atmospheric Chemistry and Physics: From Air Pollution to Climate Change, John Wiley \& Sons, 1998.

Sommariva, R., Bates, T. S., Bon, D., Brookes, D. M., de Gouw, J. A., Gilman, J. B., Herndon, S. C., Kuster, W. C., Lerner, B. M., Monks, P. S., Osthoff, H. D., Parker, A. E., Roberts, J. M., Tucker, S. C., Warneke, C., Williams, E. J., Zahniser, M. S., and Brown, S. S.: Modelled and measured concentrations of peroxy radicals and nitrate radical in the U.S. Gulf Coast region during TexAQS 2006, J. Atmos. Chem., 68, 331-362, doi:10.1007/s10874-012-9224-7, 2011.

Spracklen, D. V., Jimenez, J. L., Carslaw, K. S., Worsnop, D. R., Evans, M. J., Mann, G. W., Zhang, Q., Canagaratna, M. R., Allan, J., Coe, H., McFiggans, G., Rap, A., and Forster, P.: Aerosol mass spectrometer constraint on the global secondary organic aerosol budget, Atmos. Chem. Phys., 11, 12109-12136, doi:10.5194/acp-11-12109-2011, 2011.

Stull, R.: An Introduction to Boundary Layer Meteorology, Springer, 1998.

Thornton, J., Braban, C., and Abbatt, J.: $\mathrm{N}_{2} \mathrm{O}_{5}$ hydrolysis on submicron organic aerosols: the effect of relative humidity, particle phase, and particle size, Phys. Chem. Chem. Phys., 5, 45934603, 2003.

Tuazon, E. C., Atkinson, R., Plum, C. N., Winer, A. M., and Pitts, J. N.: The reaction of gas phase $\mathrm{N}_{2} \mathrm{O}_{5}$ with water vapor, Geophys. Res. Lett., 10, 953-956, doi:10.1029/GL010i010p00953, 1983.

Volkamer, R., Jimenez, J., San Martini, F., Dzepina, K., Zhang., Q., Salcedo, D., Molina, L., Worsnop, D., and Molina, M.: Secondary organic aerosol formation from anthropogenic air pollution: Rapid and higher than expected, Geophys. Res. Lett., 33, L17811, doi:10.1029/2006GL026899, 2006.

Wagner, N., Dube, W., Washenfelder, R., Young, C., Pollack, I., Ryerson, T., and Brown, S.: Diode laser-based cavity ring-down instrument for $\mathrm{NO}_{3}, \mathrm{~N}_{2} \mathrm{O}_{5}, \mathrm{NO}, \mathrm{NO}_{2}$ and $\mathrm{O}_{3}$ from aircraft, Atmos. Meas. Tech., 4, 1227-1240, doi:10.5194/amt-4-1227-2011, 2011.

Wahner, A., Mentel, T. F., and Sohn, M.: Gas-phase reaction of $\mathrm{N}_{2} \mathrm{O}_{5}$ with water vapor: Importance of heterogeneous 
hydrolysis of $\mathrm{N}_{2} \mathrm{O}_{5}$ and surface desorption of $\mathrm{HNO}_{3}$ in a large Teflon chamber, Geophys. Res. Lett., 25, 2169-2172, doi:10.1029/98GL51596, 1998.

Weber, R., Sullivan, A., Peltier, R., Russell, A., Yan, B., Zheng, M., de Gouw, J., Warneke, C., Brock, C., Holloway, J., Atlas, E., and Edgerton, E.: A study of secondary organic aerosol formation in the anthropogenic-influenced southeastern United States, J. Geophys. Res., 112, D13302, doi:10.1029/2007JD008408, 2007.

Winer, A. M., Atkinson, R., and Pitts, J. N.: Gaseous nitrate radical: possible nighttime atmospheric sink for biogenic organic compounds, Science, 224, 156-159, 1984.

Wooldridge, P. J., Perring, A. E., Bertram, T. H., Flocke, F. M., Roberts, J. M., Singh, H. B., Huey, L. G., Thornton, J. A., Wolfe, G. M., Murphy, J. G., Fry, J. L., Rollins, A. W., LaFranchi, B. W., and Cohen, R. C.: Total Peroxy Nitrates ( $\Sigma$ PNs) in the atmosphere: the Thermal Dissociation-Laser Induced Fluorescence (TD-LIF) technique and comparisons to speciated PAN measurements, Atmos. Meas. Tech., 3, 593-607, doi:10.5194/amt-3-5932010, 2010.
Zaveri, R. A., Easter, R. C., Fast, J. D., and Peters, L. K.: Model for Simulating Aerosol Interactions and Chemistry (MOSAIC), J. Geophys. Res., 113, D13204, doi:10.1029/2007JD008782, 2008. Zhang, Q., Jimenez, J., Worsnop, D., and Canagaratna, M.: A case study of urban particle acidity and its effect on secondary organic aerosol, Environ. Sci. Technol., 41, 3213-3219, doi:10.1021/es061812j, 2007. 